Article

\title{
Mechanisms of Convection Initiation in the Southwestern Xinjiang, Northwest China: A Case Study
}

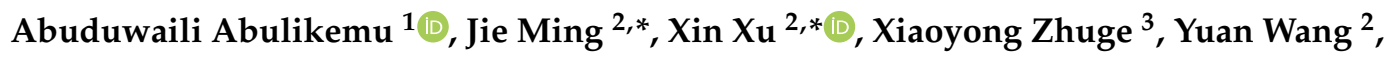 \\ Yunhui Zhang ${ }^{4}$, Shushi Zhang ${ }^{3,5}$, Bixin $\mathrm{Yu}^{4}$ and Mangsuer Aireti ${ }^{4}$ \\ 1 Key Laboratory of Oasis Ecology (Ministry of Education), College of Resources and Environment Sciences, \\ Xinjiang University, Urumqi 830046, China; abduwaly@xju.edu.cn \\ 2 Key Laboratory of Mesoscale Severe Weather (Ministry of Education), School of Atmospheric Sciences, \\ Nanjing University, Nanjing 210023, China; yuanasm@nju.edu.cn \\ 3 Nanjing Joint Institute for Atmospheric Sciences, Chinese Academy of Meteorological Sciences, \\ Nanjing 210000, China; xyzhuge@nju.edu.cn (X.Z.); zhangss@cma.gov.cn (S.Z.) \\ 4 Xinjiang Meteorological Observatory, Urumqi 830002, China; zhangyunhui226391@cma.cn (Y.Z.); \\ yubixin488554@cma.cn (B.Y.); mangsuer269004@cma.cn (M.A.) \\ 5 State Key Laboratory of Severe Weather, Chinese Academy of Meteorological Sciences, Bejing 100081, China \\ * Correspondence: jming@nju.edu.cn (J.M.); xinxu@nju.edu.cn (X.X.)
}

Received: 4 November 2020; Accepted: 2 December 2020; Published: 9 December 2020

check for updates

\begin{abstract}
The mechanism of convection initiation (CI) occurring in the Southwest Xinjiang, Northwest China is investigated using quantitative budget analysis of vertical momentum for the first time. The Weather Research and Forecasting (WRF) model is used to reproduce and analyze the CI events. The observations showed that many CIs occurred continuously, with an intense mesoscale convective system eventually forming. The overall features of the CIs were well captured by the simulation. Lagrangian vertical momentum budgets, in which the vertical acceleration was decomposed into dynamic and buoyant components, were performed along the backward trajectories of air parcels within two convective cells. The results showed that the buoyant acceleration is the major contributor in both the slow and rapid lifting period of the CI, while the dynamic acceleration also showed a considerably positive effect only during the rapid lifting period. The buoyant acceleration during the slow lifting period was due to the warm advection generated by the radiative heating near the mountainous area on the south side of Tarim Basin in the afternoon. The buoyant acceleration during the rapid lifting period was from the latent heat release within the convective cell. Further decomposition of the dynamic acceleration showed that the vertical twisting related to the vertical shear of horizontal wind almost completely dominated the dynamic acceleration, while the horizontal curvature and extension showed very weak contribution. These findings provide some new insights into the roles of buoyant and dynamic forcing in the mechanism of CI in Southwest Xinjiang.
\end{abstract}

Keywords: convection initiation; numerical modeling; vertical momentum; WRF; Xinjiang; mesoscale convective system

\section{Introduction}

Convection initiation (CI) is defined as the process by which air parcels reach a level of free convection (LFC), then achieve and maintain positive buoyancy over a significant upward vertical motion, and eventually lead to the development of a deep convective cloud [1]. CI has long been one of the primary foci of studies on deep moist convection because it is essential in the organization and 
development of mesoscale convective storms [2-9]. The accurate prediction of CI remains one of the biggest challenges in weather forecasting [5,10-14].

The CI has been studied extensively around the world [2-8,12,15-17]. Lock and Houston [5] studied over 55,000 CI cases over the central United States from 2005 to 2007, and found that there are four primary parameters governing the behavior of $\mathrm{CI}-$ i.e., buoyancy, inhibition, dilution and vertical lifting. They pointed out that there is no threshold of any single factor that is able to discriminate between initiation and non-initiation. However, they stated that vertical lifting could be seen as the most frequent factor that helps distinguish the CI environment. As such, Markowski [1] stated that vertical lifting plays a decisive role in $\mathrm{CI}$, including that caused by convergent boundary zones (e.g., fronts, cold pool outflow boundaries, sea/land breezes, and dry lines), forced lifting by gravity waves, ascending airflow over orography, and circulations driven by differential heating (e.g., cloud-clear air boundaries, horizontal sensible heat flux variations and heating of sloped terrain). Banta and Schaaf [18] pointed out some topographic features with a high likelihood of CI. They discussed several CI mechanisms over the mountains, such as leeside convergence, orographic lifting, channeling, and wake effects. Similarly, Weckwerth et al. [19] identified CI-prone zones that were active under certain wind circumstances, according to a 9-y CI dataset over a complex topography in Europe, and they also found that CI preferentially occurred over the local higher terrains such as mountain slopes or peaks. Jeong et al. [20] investigated a mesoscale convective system (MCS) in the southeast of South Korea and found that many CIs occurred repeatedly near the leading edge of a cold pool gust front. They concluded that the cold pool played a crucial role in the stationarity of the MCS, causing extreme rainfall over the Busan metropolitan area. Wang et al. [21] studied two cases of CI forced by the lake-breeze convergence over the Southern Ontario, ON, Canada. They found that the collision of two lake-breeze fronts (originated from Lake Ontario and Lake Erie, respectively) over the Niagara Peninsula and the resulting enhancement of sub-cloud ascent caused the formation and/or intensification of convection.

The analysis method of the Lagrangian vertical momentum budget has been used in studies of MCSs in many places, such as in the United States, which highlighted the vital role of either flow shear on the horizontal plane (in terms of vertical vorticity [22,23]) or flow extension ([24,25]). These studies focused on different dynamical processes which result in dynamic acceleration (i.e., genesis of tornados [22]; genesis of meso-vortex within isolated supercell or MCS [23]; rear-inflow jet [24]; internal outflow surge which triggers tornado [25]).

Previous studies about CI in China mainly focused on the relatively developed areas in the central, eastern, northern and southern parts $[8,9,26-37]$. They found that many convective cells were repeatedly initiated due to the dynamic effect of mesoscale systems, such as Meiyu front, cold pool outflows (gust fronts), dry line, low-level jet (LLJ), prevailing low-level monsoonal wind and land/sea breeze. However, to our knowledge, there has been no in-depth quantitative diagnostic study on the CI mechanisms in the southwestern Xinjiang province in Northwest China in the literature. As the center of Eurasia, this area is among the most arid region where the ecological environment is fragile. Consequently, the overall characteristics of weather systems and the associated natural disasters in this area significantly differ from those in other parts in China, which represent humid monsoon climate. Therefore, the present study aims to investigate a CI event which produced heavy rainfall, high wind and hail in this area by exploiting observations in conjunction with the Lagrangian vertical momentum budget analyzes based on a numerical simulation.

The rest of this paper is organized as follows. Section 2 gives a brief overview of the severe convective event. Section 3 presents the numerical simulation setup and model verification. The mechanism of CI is documented in Section 4, according to the analysis of vertical momentum budget. Finally, a summary and discussion are presented in Section 5.

\section{Case Overview}

A severe convective storm occurred in southwestern Xinjiang, Northwest China (Figure 1) from 0900 to 1800 UTC on 23 June 2015. The convective weather produced short-term high winds, 
heavy rainfall (up to $20.8 \mathrm{~mm}$ in $30 \mathrm{~min}$, which is considered extreme rainfall in arid regions) and hail with a diameter of $20 \mathrm{~mm}$. Besides, more than 1239 hectares of crops, including corn, cotton, watermelon and wheat, were damaged.

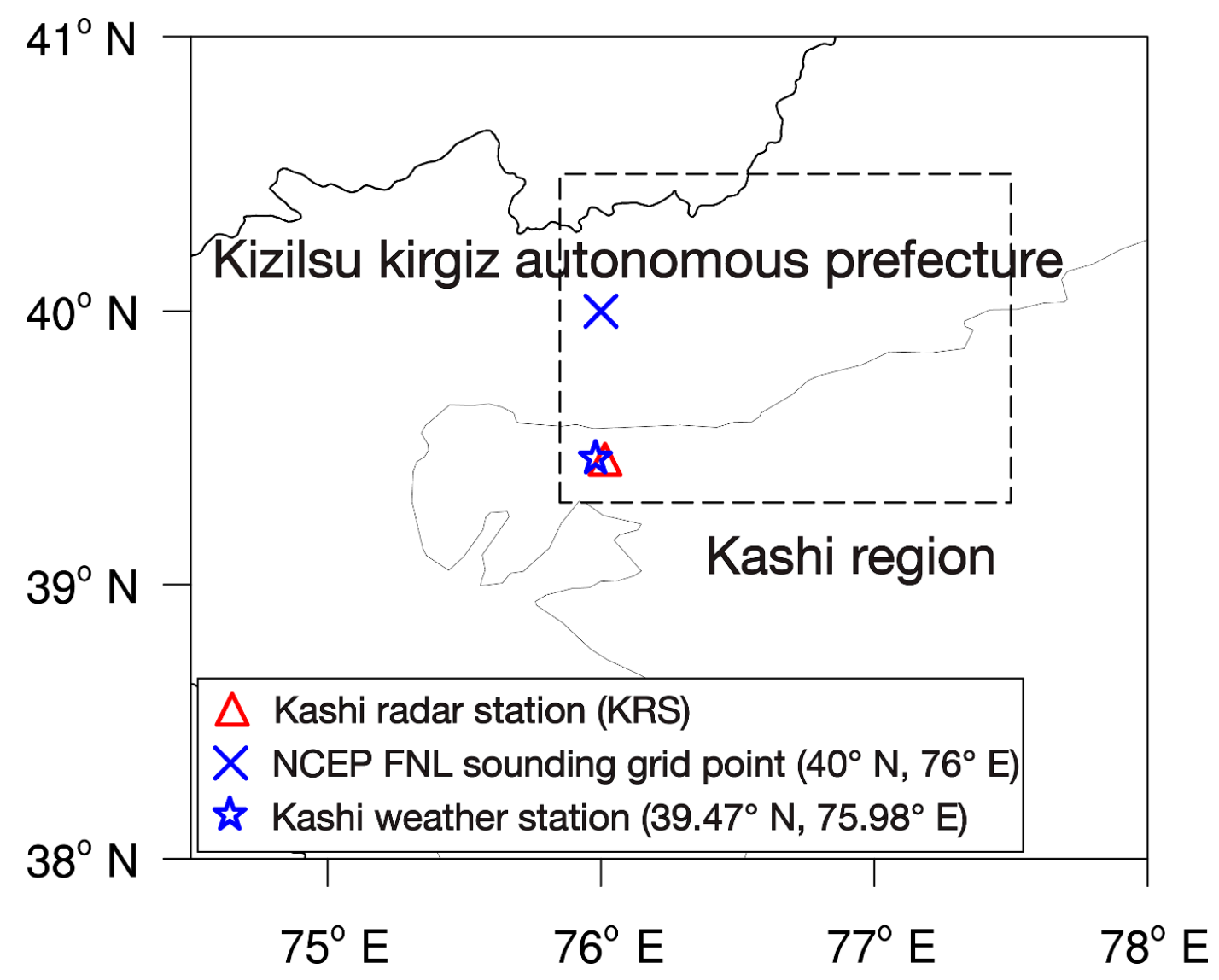

Figure 1. Study area where the severe convective weather occurred. It is located in the innermost domain (d04) in Figure 5. The solid black and gray lines indicate the national and district boundaries, respectively. Dashed rectangle area indicates the area analyzed in Figures 4, 6 and 8.

\subsection{Environmental Conditions}

In order to investigate the environmental conditions of this severe convective weather, the six-hourly National Centers for Environmental Prediction (NCEP) Final (FNL) analysis dataset with a resolution of $1^{\circ} \times 1^{\circ}$ was analyzed. As shown in Figure 2a, a moderately intense cold low (indicated by bold blue letter "L") was located over the area between Aral Sea and Balkhash Lake at $500 \mathrm{hPa}$ at 0000 UTC on 23 June 2015. It showed a "cut-off low" feature with a closed isoheight and two closed isotherms; however, the cold center was not collocated with the low center. A trough showing a distribution along the north-south direction can be identified according to the wind field. The severe convective weather occurred in the study area ahead of the trough. Westerlies dominated in an area to the south-west of the study area which is believed to be critical for the moisture advection (labelled as "upstream critical area" in Figure 2).

By 0600 UTC (Figure 2b), the dominant winds in the upstream critical area changed to southwesterlies, with the trough nearby moving slightly eastward. These southwesterlies brought warm and moist air (i.e., high equivalent potential temperature, $\theta_{e}$ ) to the study area. At $700 \mathrm{hPa}$ (Figure 2c), the cold center was located slightly south of the mid-level (500 hPa) cold center, with the trough seeming to become smaller in size. Winds in the upstream critical area were rather weak (about 2-4 $\mathrm{m} \cdot \mathrm{s}^{-1}$ ), and most of them were easterlies. Besides, some southwesterlies (about 6-8 $\mathrm{m} \cdot \mathrm{s}^{-1}$ ) can also be found in the further southwestern part of the upstream critical area. By 0600 UTC (Figure 2d), 
the winds in the center area changed to southerlies, and winds at the southwestern part increased somewhat (up to $\sim 10 \mathrm{~m} \cdot \mathrm{s}^{-1}$ ) and came from the west-southwest direction. These southwesterlies came from a warm and moist region with high equivalent potential temperature $\left(\theta_{e}\right)$, which was conducive to the water vapor transport.

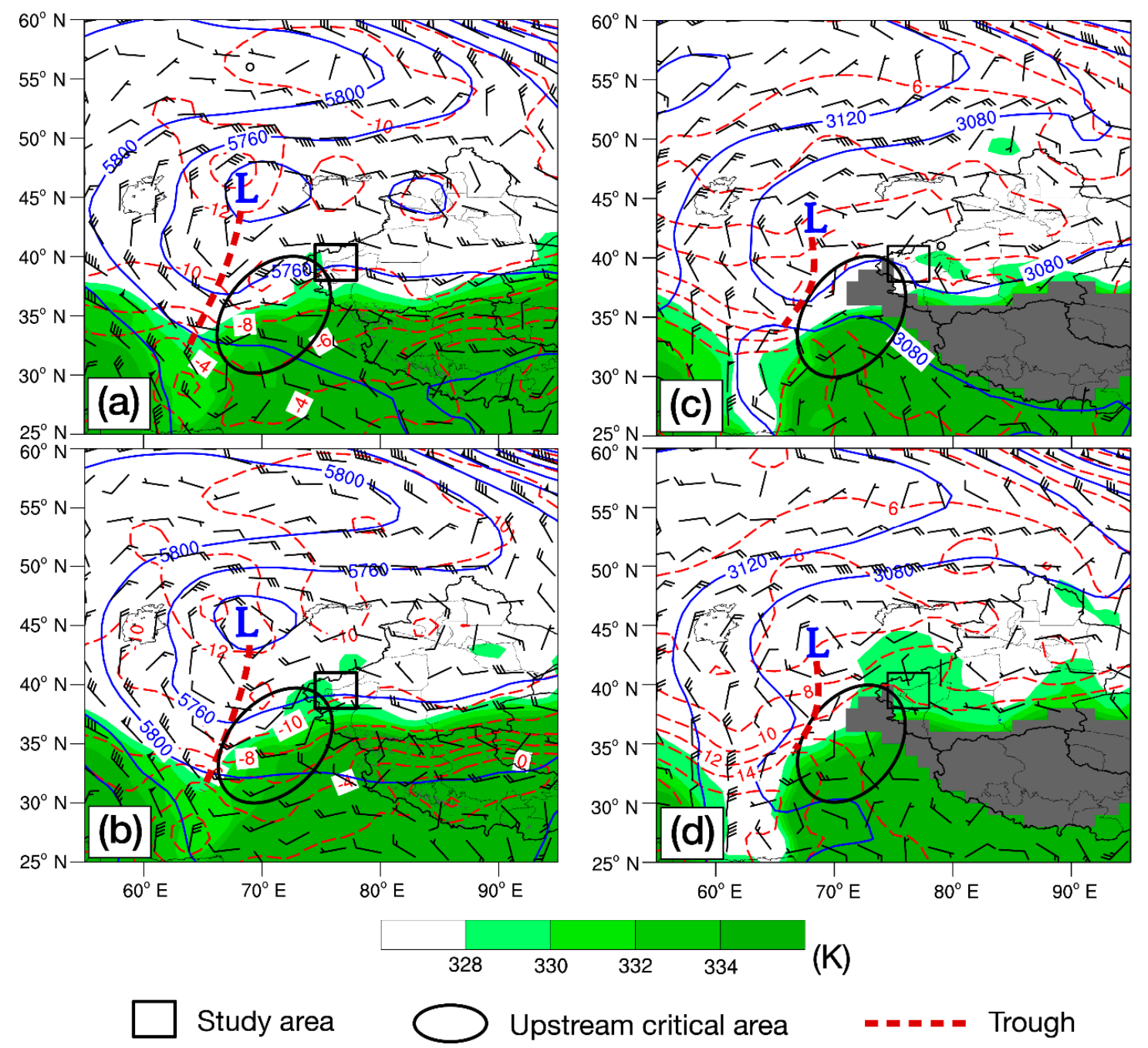

Figure 2. (a,b) Equivalent potential temperature ( $\theta_{e}$, green shading; unit: $\mathrm{K}$ ) in excess of $328 \mathrm{~K}$, geopotential height (blue solid contours; unit: gpm), temperature (red dashed contours; unit: ${ }^{\circ} \mathrm{C}$ ) and wind field (half barbs; full barbs and flags represent 2, 4 and $20 \mathrm{~m} \cdot \mathrm{s}^{-1}$, respectively) at $500 \mathrm{hPa}$ on 23 June 2015. (c,d) are the same as $(\mathbf{a}, \mathbf{b})$, but for the values at $700 \mathrm{hPa}$; the gray shading represents for the Tibet Plateau with ground pressure below $700 \mathrm{hPa}$. The specific time is shown in the upper right corner of each panel.

There was no convective available potential energy (CAPE) in an observed sounding analysis at 0000 UTC on 23 June (Figure 3a). The atmosphere was rather dry near the surface, showing a large dewpoint depression ( $T-T d$ ) of $\sim 17 \mathrm{~K}$. However, the relative humidity increased quickly with height and reached a dewpoint depression of $\sim 6 \mathrm{~K}$ at about $650 \mathrm{hPa}$. The dewpoint temperature profile showed a jagged pattern in the upper level between 650 and $400 \mathrm{hPa}$, presenting a stratification alternatively with relatively dry and moist levels. The upper level between 500 and $400 \mathrm{hPa}$ was relatively moist, showing an almost saturated condition (i.e., dewpoint depression decreased to $\sim 1 \mathrm{~K}$ ) at about $460 \mathrm{hPa}$, while the humidity decreased significantly above $300 \mathrm{hPa}$. There was a warm advection 
indicated by the veering vertical shear of horizontal wind (from westerlies to northwesterlies) in this relatively moist layer between 500 and $300 \mathrm{hPa}$.
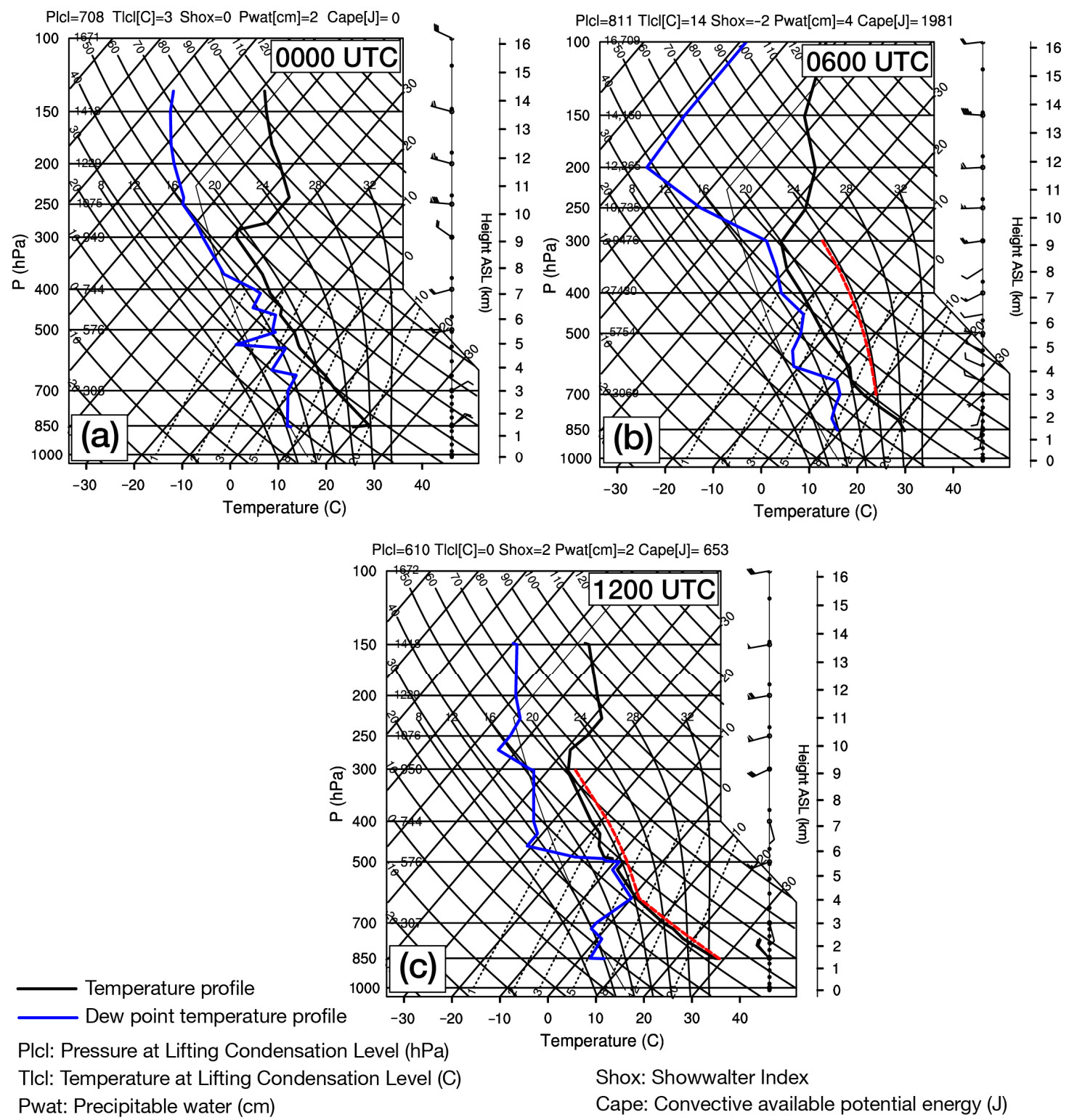

Figure 3. (a,b) Skew T-logP diagram derived from observed balloon sounding at Kashi weather station and the NCEP FNL data (see Figure 1) on 23 June 2015. (c) is the same as (a), but for the observation at 1200 UTC on 23 June 2015. The CAPE was calculated based on the air parcel from the surface. The specific time is shown in the upper right corner of each panel.

Since the sounding observations in China are twice daily at 0000 UTC and 1200 UTC, a representative sounding derived from the NCEP FNL analysis data was analyzed at 0600 UTC in order to examine the environmental conditions more close to the occurrence of the severe storm (Figure 3b). This exhibited a relatively high CAPE of $1981 \mathrm{~J} \cdot \mathrm{kg}^{-1}$, with a similar dry condition near the surface, showing a dewpoint depression of $\sim 14 \mathrm{~K}$. The humidity increased with height and reached a dewpoint depression of $\sim 3 \mathrm{~K}$ at about $670 \mathrm{hPa}$, while the humidity at about $600 \mathrm{hPa}$ showed a relatively dry condition with a dewpoint depression of $\sim 12 \mathrm{~K}$. However, the level from 500 to $300 \mathrm{hPa}$ was rather moist (the dewpoint depression decreased to $2-4 \mathrm{~K}$ ) and was dominated by the westerlies and southwesterlies in the layer from 450 to $300 \mathrm{hPa}$. By 1200 UTC (Figure 3c), the CAPE 
decreased significantly to $653 \mathrm{~J} \cdot \mathrm{kg}^{-1}$, with the surface becoming rather dry (the dewpoint depression reached $\sim 25 \mathrm{~K}$ ). However, the level between $\sim 600$ and $500 \mathrm{hPa}$ showed an almost saturated condition (i.e., the dewpoint depression decreased to $\sim 1 \mathrm{~K}$ ), while the upper level above $500 \mathrm{hPa}$ became relatively dry. Furthermore, there was a warm advection indicated by the veering of the horizontal wind with height (from southerlies to west-southwesterlies) in the layer from 700 to $500 \mathrm{hPa}$.

\subsection{System Evolution}

The $\mathrm{CI}$ is often defined as the first occurrence of radar reflectivity over $35 \mathrm{dBZ}$ within a convective cell (e.g., [3,30,31,38,39]). The evolution of the CI features and the associated severe convective system were observed by the Kashi Doppler weather radar. (All the observation data were provided by the National Meteorological Center of the China Meteorological Administration (CMA)). At 1004 UTC (Figure 4a), a convective cell initiated about $50 \mathrm{~km}$ to the northeast of the Kashi radar station (KRS). Several other convective cells appeared nearby at 1016 UTC (Figure 4b), they extend to a height of about $2.5-8 \mathrm{~km}$ AGL (figure not shown). In the following $\sim 1 \mathrm{~h}$ (Figure $4 \mathrm{c}-\mathrm{g}$ ), there were more than 10 convective cells, and some of them merged together and developed significantly in both size and intensity. By 1130 UTC (Figure 4h), a relatively intense MCS developed with an orientation in the northwest-southeast direction.

In general, more than half of the convective cells underwent rapid development, and eventually formed an intense MCS. This may account for the major severe convective storm in this area. In the following section, numerical simulations are conducted to study the mechanisms of the CIs.

\section{Numerical Simulation}

\subsection{Simulation Setup}

The simulation was conducted by using the Weather Research and Forecasting (WRF) model (V3.7, [40]), with two-way nested quadruple-level domains and horizontal grid spacings of $45 \mathrm{~km}$, $9 \mathrm{~km}, 3 \mathrm{~km}$ and $1 \mathrm{~km}$, respectively (Figure 5). The innermost domain (d04) fully covers the area where the convective weather of interest occurred (Figure 1). In order to successfully simulate the CIs and the associated convective system, it is important to properly represent the large-scale circulation, which requires a large model domain. Hence, the outermost domain (d01) covers almost the whole central and western Asia (see Figure 5). Due to the limitation of the computational cost, the resolution of domain $\mathrm{d} 01$ is set to $45 \mathrm{~km}$ which is five times that of the $\mathrm{d} 02$. However, in order to reduce the calculation error as much as possible, the grid ratio is set to 3 in the inner domains. (A similar grid ratio was adopted in previous studies (e.g., [31,41])). There are 55 vertical levels (terrain-following) from the surface to the model top at $50 \mathrm{hPa}$. For all the four domains, the model physics adopts the WRF Single Moment 6-class (WSM6) microphysics scheme [42], Asymmetric Convective Model 2 (ACM2) planetary boundary layer (PBL) scheme [43], Rapid Radiative Transfer Model (RRTM) longwave and shortwave radiation schemes [44], Unified Noah land surface model scheme [45] and Revised MM5 (Fifth-Generation Penn State/National Center for Atmospheric Research Mesoscale Model) Monin-Obukhov scheme [46]. The Kain-Fritsch scheme [47] was used for cumulus parameterization in domains d01 and d02, while it was turned off in domains d03 and d04. (Above physical parameterization schemes were selected as the most appropriate combination based on the results of a dozen experiments.) The initial and boundary conditions were created by using the 6-hourly NCEP FNL analysis data with a resolution of $1^{\circ} \times 1^{\circ}$. All domains were initialized at 0000 UTC on 23 June 2015 and integrated for $18 \mathrm{~h}$. The time intervals of the output data of d01, d02 and d03 are $60 \mathrm{~min}, 20 \mathrm{~min}$ and $3 \mathrm{~min}$, respectively. 

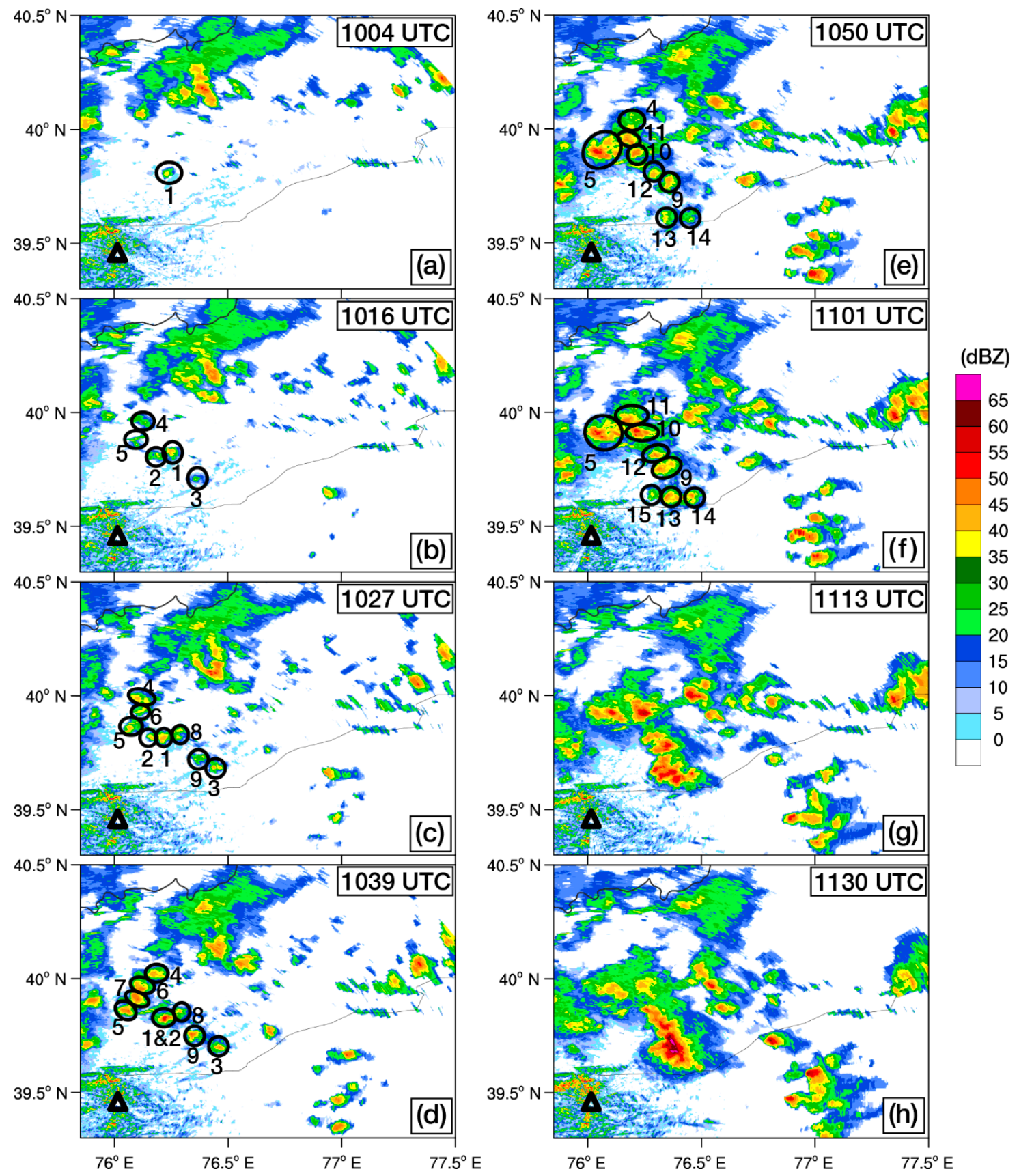

Figure 4. (a-h) Observed composite reflectivity (shading; unit: dBZ) observed at KRS (indicated by black triangle) at different times from 1004 UTC to 1130 UTC on 23 June 2015. The convective cells are numbered in time order and indicated by black circles. The specific time is shown in the upper right corner of each panel. 


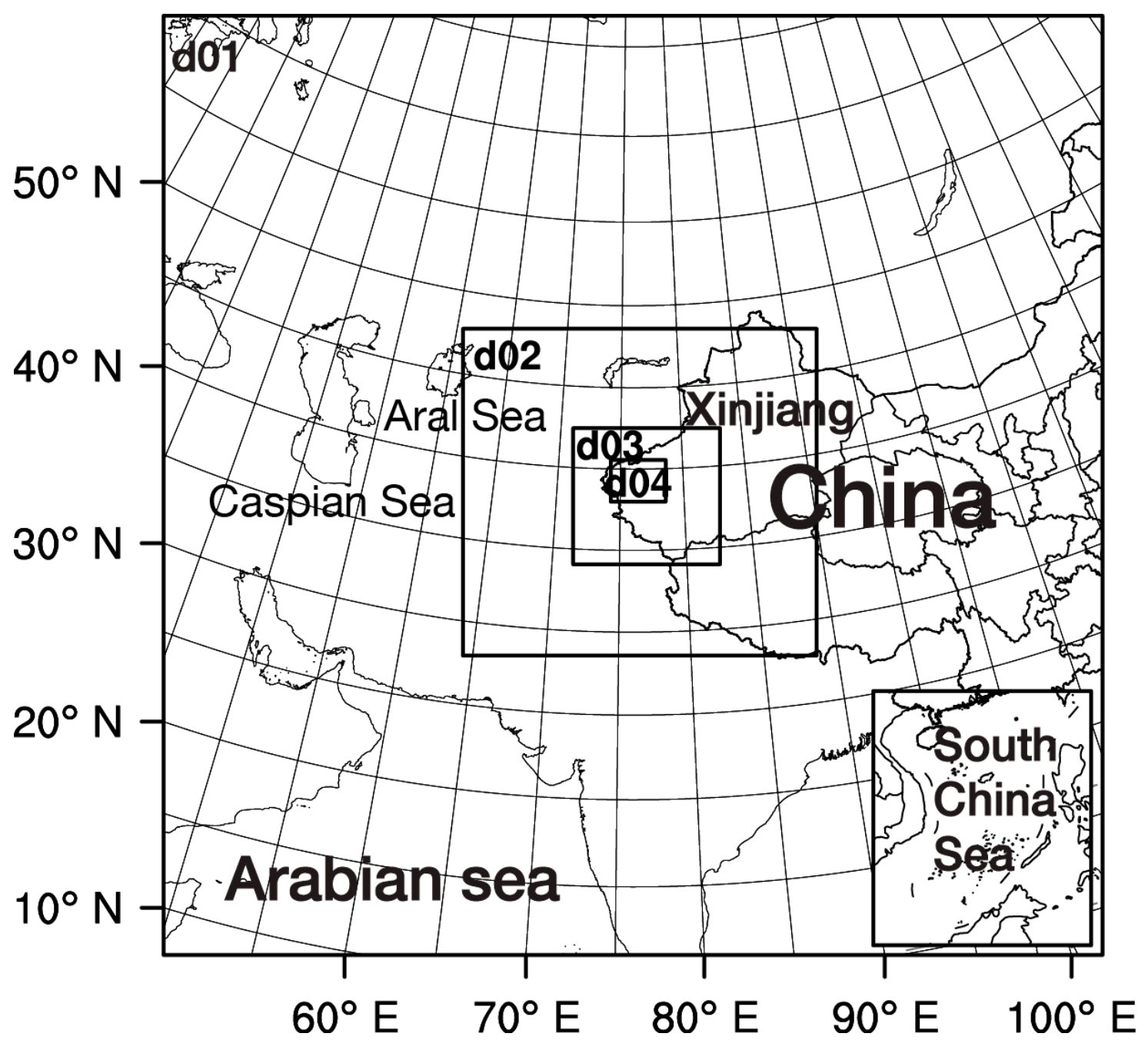

Figure 5. Geographic locations of the WRF model domains. The innermost domain (d04) covers the whole study area, as shown in Figure 1.

\subsection{Verification of Simulation}

In order to establish the credibility of numerical simulation, we firstly compare the simulated composite reflectivity and 8-h accumulated precipitation with observations in the following.

The model results showed that several CIs (indicated by ellipse) occurred continuously in an area about $40-50 \mathrm{~km}$ northeast of the KRS, although they developed about $1.5 \mathrm{~h}$ later than their observational counterparts and were displaced by $\sim 10 \mathrm{~km}$ to the southeast (Figure $6 \mathrm{~d}$ ). Over time, several other CIs occurred continuously nearby (Figure 6e), showing a distribution along the northwest-southeast direction, which were in agreement with the observations. More than half of these convective cells underwent rapid development in both size and intensity and eventually formed a loosely organized MCS (indicated by ellipse in Figure 6f), but with lower estimated intensity (less than $~ 60 \mathrm{dBZ}$ ). 


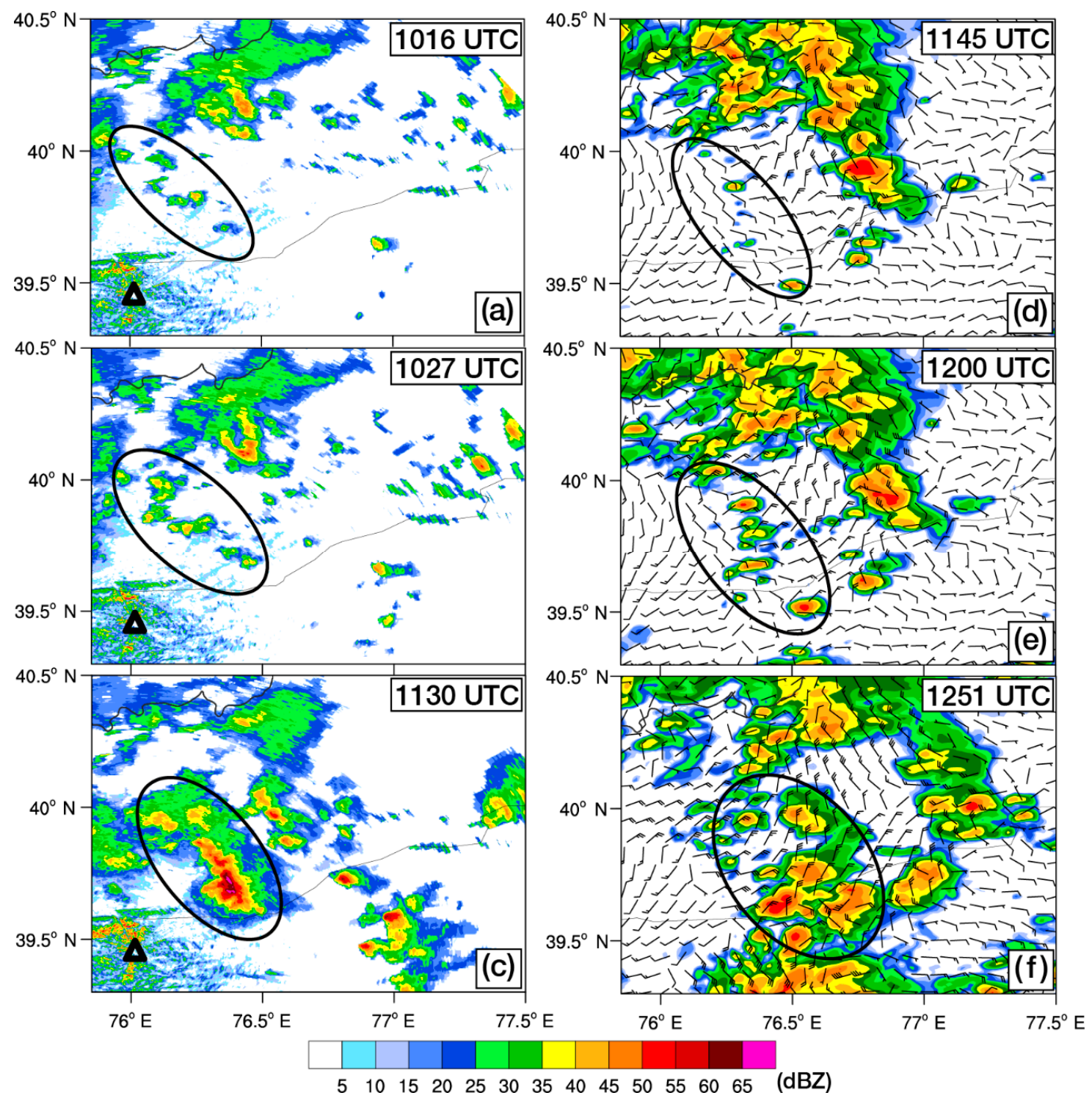

Figure 6. (a-c) Observational composite reflectivity (left panels, shading; unit: dBZ) derived from KRS (indicated by black triangle) on 23 June 2015. (d-f) Simulated composite reflectivity (right panels, shading; unit: dBZ) and ground-based relative wind field (full and half barbs represent 4 and $2 \mathrm{~m} \cdot \mathrm{s}^{-1}$, respectively) at the height of $10 \mathrm{~m}$ above the ground level on 23 June 2015 . The specific time is shown in the upper right corner of each panel.

Figure 7 compares the observations of simulated 8-h accumulated precipitation. Due to the relatively sparse population, lagged economic development and harsh environment such as desert and gobi, there are only several conventional meteorological stations and 11 surface automatic stations which have valid precipitation records in the plotted area. The accumulated precipitation also showed some biases in time $(\sim 1 \mathrm{~h})$, location and distribution pattern due to the biases of time, location and the intensity of the simulated MCS. However, two areas of high accumulated precipitation (indicated by black ellipses) can be identified in the simulation, consistent with the observations. (The Cressman interpolation was used in the observation, as it performs the best among the four methods (i.e., Cressman, natural neighbor, inverse distance weighted and tension splines) tried in this case.) 


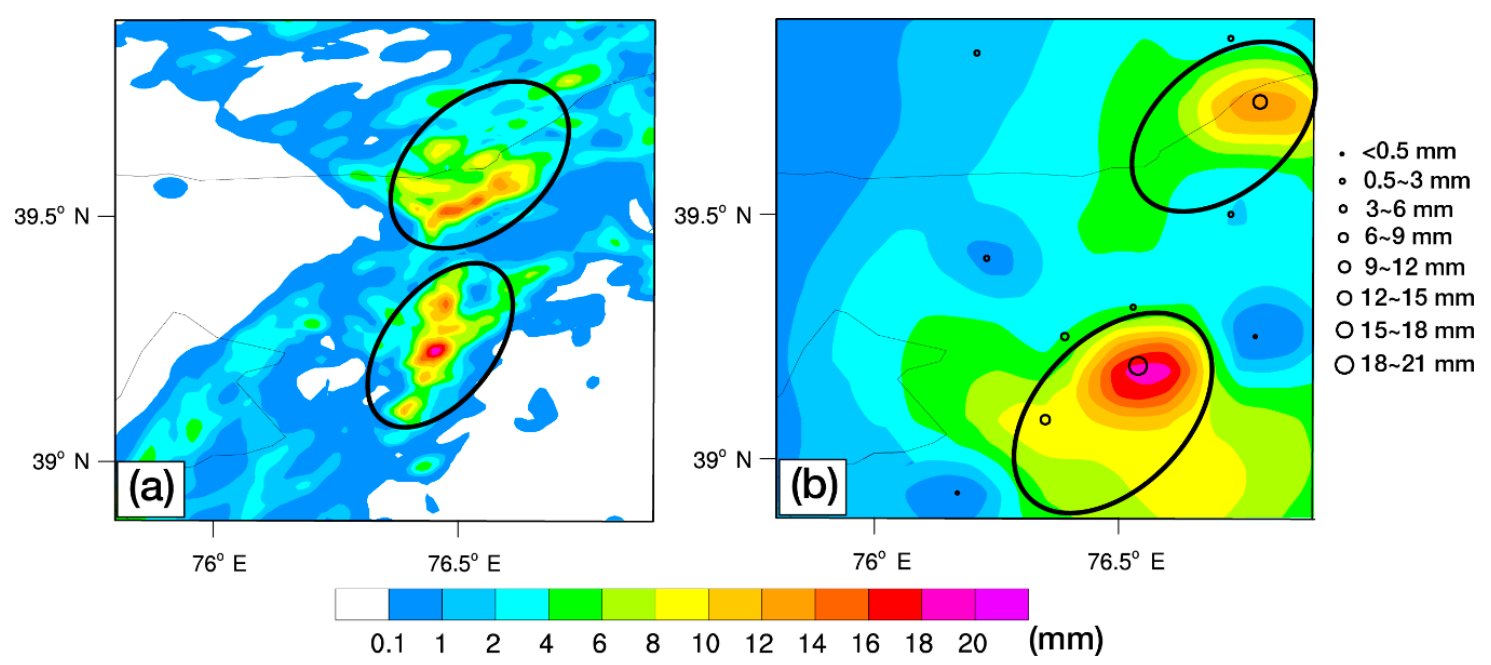

Figure 7. (a) Simulated 8-h accumulated precipitation (units: $\mathrm{mm}$ ) from 1000 to 1800 UTC 23 June 2015. (b) 8-h accumulated precipitation (shading, units: $\mathrm{mm}$ ) observed by the ground-based automatic stations (indicated by small black circles) from 0900 to 1700 UTC 23 June 2015.

The overall pattern of the CIs and related features (e.g., preciptiation) were well captured by the WRF simulation despite some timing and positioning biases. Therefore, the model results are considered to be reliable for the analysis of the CI mechanisms in the next section.

\section{Convection Initiation}

In order to investigate the mechanisms of CIs, the Lagrangian vertical momentum budgets were conducted along the backward trajectories of air parcels within two typical convective cells initiated (i.e., the maximum reflectivity of the cells reached $35 \mathrm{dBZ}$ for the first time) at 1133 and $1142 \mathrm{UTC}$, respectively (labeled as $\mathrm{C} 1$ and $\mathrm{C} 2$, indicated by black boxes in Figure 8). The backward trajectories of air parcels were computed using the fourth-order Runge-Kutta scheme, which was also used by Xu et al. [32] and Abulikemu et al. [30,31]. The air parcels within the two convective cells were released at their individual $\mathrm{CI}$ times and traced backwards for $2 \mathrm{~h}$. In order to concentrate on the parcels, which were mainly responsible for the CI (ascended significantly during the CI), the air parcels with vertical velocities in the top $25 \%$ quantile at the CI time were selected for further investigation.

The ground-relative backward trajectories of air parcels selected within two convective cells showed that (Figure 9a,b), the air parcels selected within C1 came from southwest direction. For C2, the backward trajectories could be divided into two groups, and they roughly showed that some air parcels came from a southwestern direction while the others were from the south. The height variation of the air parcels during the 2-h period prior to CI showed that (Figure 9c,d) most of the air parcels within $\mathrm{C} 1$ moved almost horizontally, while a few of them descended, to some extent, during the first one hour. However, the most significant ascending can be found in the second 1-h period. Most of the parcels released from $\mathrm{C} 2$ ascended slightly in the first 1-h period, while significant lifting can be found in the latter $1 \mathrm{~h}$. Therefore, only the features of air parcels in the 1-h period prior to the CI will be investigated in the following sections. 


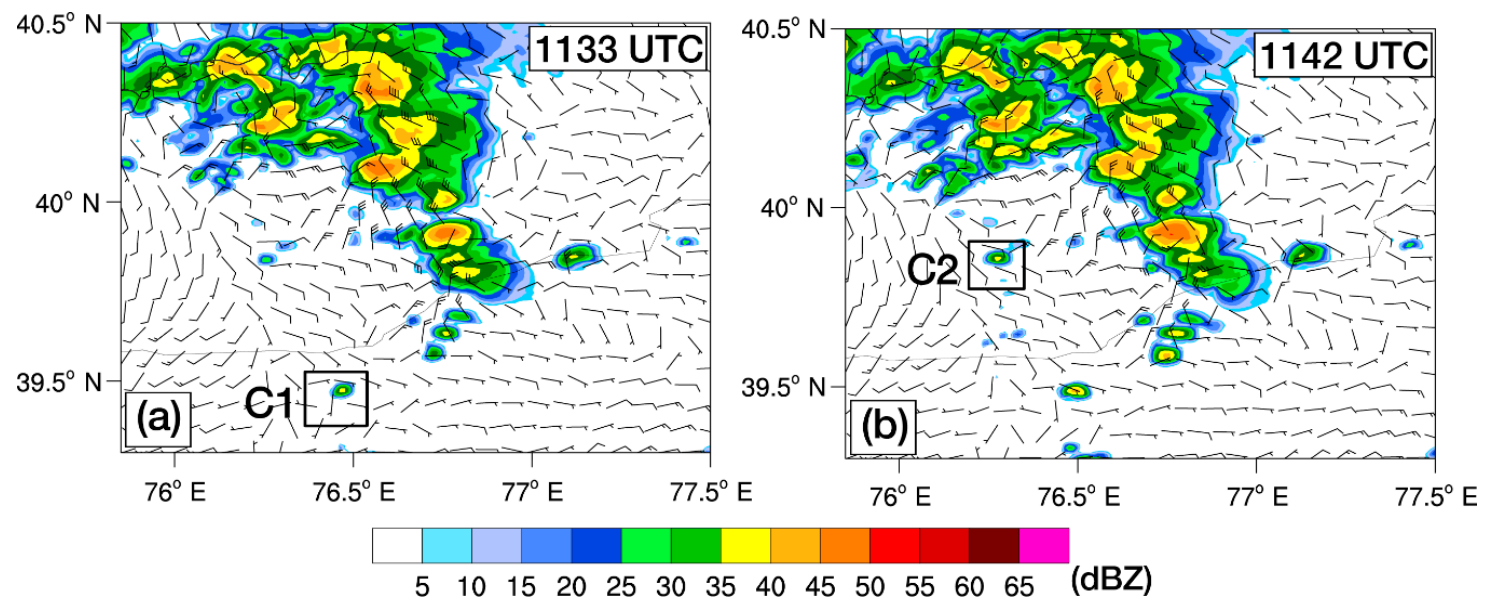

Figure 8. (a) Simulated composite reflectivity (shading; unit: dBZ) and ground relative wind field (full and half barbs represent 4 and $2 \mathrm{~m} \cdot \mathrm{s}^{-1}$, respectively) at the height of $10 \mathrm{~m}$ above the ground level on 23 June 2015 for C1. (b) is the same as (a) but for the C2. The black boxes in both panels denote the area where the two convective cells occurred for the first time. The specific time is shown in the upper right corner of each panel.
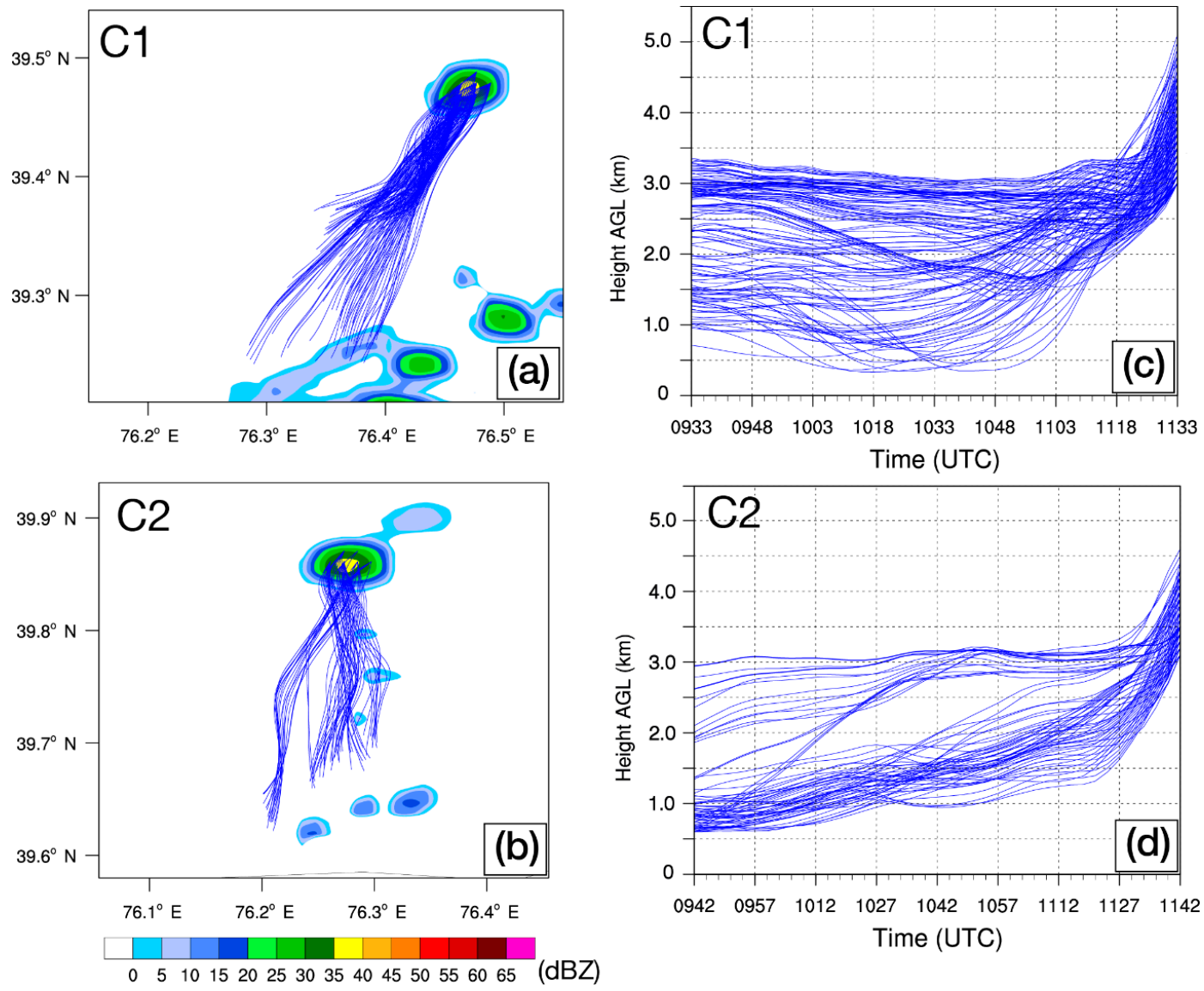

Figure 9. (a,b) Simulated composite reflectivity (shading; unit: dBZ) and ground-relative backward trajectories (blue lines, projected to the ground) of air parcels for $2 \mathrm{~h}$ within the two convective cells released at the CI time of 1133 and 1142 UTC, respectively, on 23 June 2015. (c,d) Height along the backward trajectories of air parcels within the two convective cells. 
In order to explore the CI mechanism, Lagrangian vertical momentum budgets were analyzed along the backward trajectories of air parcels within the two cells. According to Jeevanjee and Romps [48], the vertical acceleration can be decomposed into two parts, namely, buoyant acceleration $\left(a_{b}\right)$ and dynamic acceleration $\left(a_{d}\right)$-i.e.,

$$
\frac{d w}{d t}=a_{b}+a_{d}
$$

where $a_{b}$ and $a_{d}$ can be obtained from the following Poisson equations:

$$
\begin{gathered}
\nabla^{2}\left(\bar{\rho} a_{b}\right)=-g \nabla_{h}^{2} \rho \\
\nabla^{2}\left(\bar{\rho} a_{d}\right)=\frac{\partial}{\partial z} \nabla \cdot[\bar{\rho}(\vec{V} \cdot \nabla) \vec{V}]
\end{gathered}
$$

where $\vec{V}$ is the three-dimensional (3D) wind, $g$ is the acceleration of gravity, $\rho$ is the total density including hydrometeors, $\nabla^{2}$ and $\nabla^{2}{ }_{h}$ are the 3D and horizontal Laplacian operators, respectively. According to Jeevanjee and Romps [48], $a_{b}$ is defined as the Lagrangian vertical acceleration due to the horizontal variation of density, including both the Archimedean buoyancy $(B)$ and the response of the environment to the acceleration due to the $B\left(B=g \rho^{\prime} / \bar{\rho}, \bar{\rho}\right.$ represents the base-state air density which is a function of height (anelastic approximation). $\rho^{\prime}$ is the density perturbation relative to $\bar{\rho}$.) By this definition, ambiguities in the arbitrary definition of the base state density can be avoided, as mentioned in many previous studies (e.g., [41,49-51]). $a_{d}$ is defined as the Lagrangian vertical acceleration, resulting from the instantaneously zeroing out of all anomalies of horizontal density. The multigrid software for elliptic partial differential equations (abbreviated as MUDPACK [52]) was used to solve the above two Poisson equations (as suggested by Schenkman et al. [25] and Dawson et al. [53]). The Direchlet boundary conditions ( $a_{b}=0$ and $\left.a_{d}=0\right)$, which were considered to be the most appropriate and unambiguous boundary conditions [48], were adopted on both the bottom and top boundaries.

Figure 10a,b show the time evolutions of the averaged height, vertical momentum tendencies induced by buoyancy $\left(a_{b}\right)$, dynamical force $\left(a_{d}\right)$ and sum of them $\left(a_{b}+a_{d}\right)$ along all the air parcels selected within the two convective cells in the 1-h period prior to the $C I$. The averaged height of the air parcels for both convective cells exhibited a slow lifting in the early $45 \mathrm{~min}$, while it increased significantly in the last $\sim 15 \mathrm{~min}$. The averaged $a_{b}$ along the all air parcels within the $C 1$ was obviously greater than $a_{d}$ in the whole 1-h period prior to the CI, and become more intense in the last $15 \mathrm{~min}$. The $a_{d}$ showed a slight positive value in the last $\sim 10 \mathrm{~min}$, while it was negative in the earlier $\sim 50 \mathrm{~min}$. For $\mathrm{C} 2, a_{b}$ was slightly greater than $a_{d}$ in almost the whole 1-h period prior to the CI, and also increased significantly in the last $15 \mathrm{~min}$. The $a_{d}$ exhibited very weak negative value in the early $\sim 45 \mathrm{~min}$, while increased significantly during the last $\sim 12 \mathrm{~min}$, and showed almost the same value with $a_{b}$ at $\sim 3$ min prior to the CI. For both convective cells, the $a_{b}$ was significantly greater than $a_{d}$ in the last 3 $\mathrm{min}$. In general, from an overall perspective of the average trajectory of the air parcels, $a_{b}$ is the major contributor to CI for all two convective cells, with $a_{d}$ also showing some positive effect on the CI.

In order to investigate the intuitional physical meanings of $a_{d}$, the forcing term on the right hand side of Equation (3) was decomposed into the following components under the assumption of anelastic approximation [22]-i.e.,

$$
\begin{gathered}
\nabla \cdot\left[\bar{\rho}_{(z)}(\vec{V} \cdot \nabla) \vec{V}\right]= \\
\bar{\rho}_{(z)}\left[\left(\frac{\partial u}{\partial x}\right)^{2}+\left(\frac{\partial v}{\partial y}\right)^{2}+\left(\frac{\partial w}{\partial z}\right)^{2}-w^{2} \frac{d^{2} \ln \left(\bar{\rho}_{(z)}\right)}{d z^{2}}\right] \\
+2 \bar{\rho}_{(z)}\left(\frac{\partial v}{\partial x} \frac{\partial u}{\partial y}\right)
\end{gathered}
$$




$$
+2 \bar{\rho}_{(z)}\left(\frac{\partial w}{\partial x} \frac{\partial u}{\partial z}+\frac{\partial w}{\partial y} \frac{\partial v}{\partial z}\right)
$$

where terms (4a) indicate the fluid extensions, terms (4b) and (4c) denote the horizontal curvature and vertical twisting. The term (4b) is proportional to the vertical vorticity for a pure rotational flow [22], while term (4c) can be considered to be related to the horizontal vorticity (i.e., rotation in the vertical plane). Contributions of the three terms to the total dynamic forcing can be calculated via substituting each of them into the right-hand side of Equation (3) and solving the relevant Poisson equations.
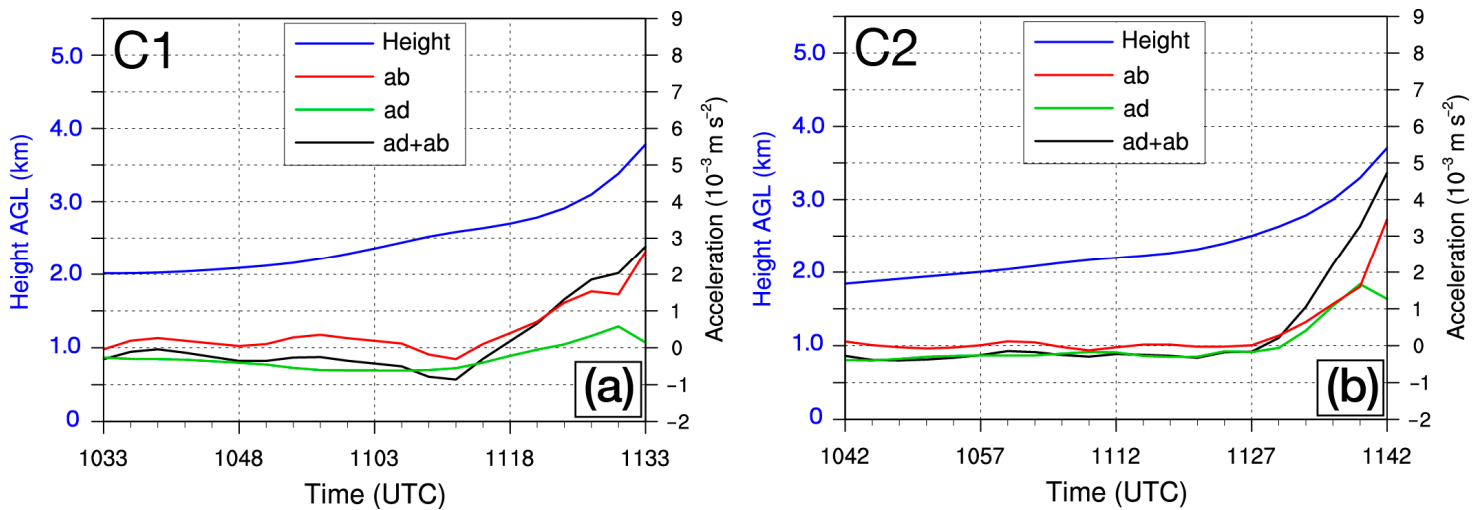

Figure 10. (a) Averaged height and vertical momentum components induced by buoyancy $\left(a_{b}\right)$, dynamical force $\left(a_{d}\right)$ and sum of them $\left(a_{b}+a_{d}\right)$ along all air parcels selected within the $\mathrm{C} 1$. (b) is the same as (a) but for the $\mathrm{C} 2$.

Evolutions of the averaged three components of $a_{d}$ along the backward trajectories of air parcels within two convective cells are shown in Figure 11a,b. The extension term revealed relatively small positive contributions to the total $a_{d}$ in the early $\sim 48 \mathrm{~min}$, while its contributions clearly decreased to a negative value in the last $\sim 10 \mathrm{~min}$ prior to the $\mathrm{CI}$. The horizontal curvature term showed a very small effect on $a_{d}$ during almost the whole period. For both convective cells, the vertical twisting term had a negative effect during the early $\sim 48 \mathrm{~min}$, while it showed a significant increasing trend and dominated the whole $a_{d}$ during the last 10-12 min prior to the CI. Especially in the last $10 \mathrm{~min}$, the vertical twisting term was remarkably greater than all the other terms. In general, the overall evolution of $a_{d}$ was consistent with that of the vertical twisting term in the rapid lifting period of the last $\sim 12 \mathrm{~min}$ prior to the CI. Therefore, it can be concluded that $a_{d}$ was mainly caused by the vertical twisting.
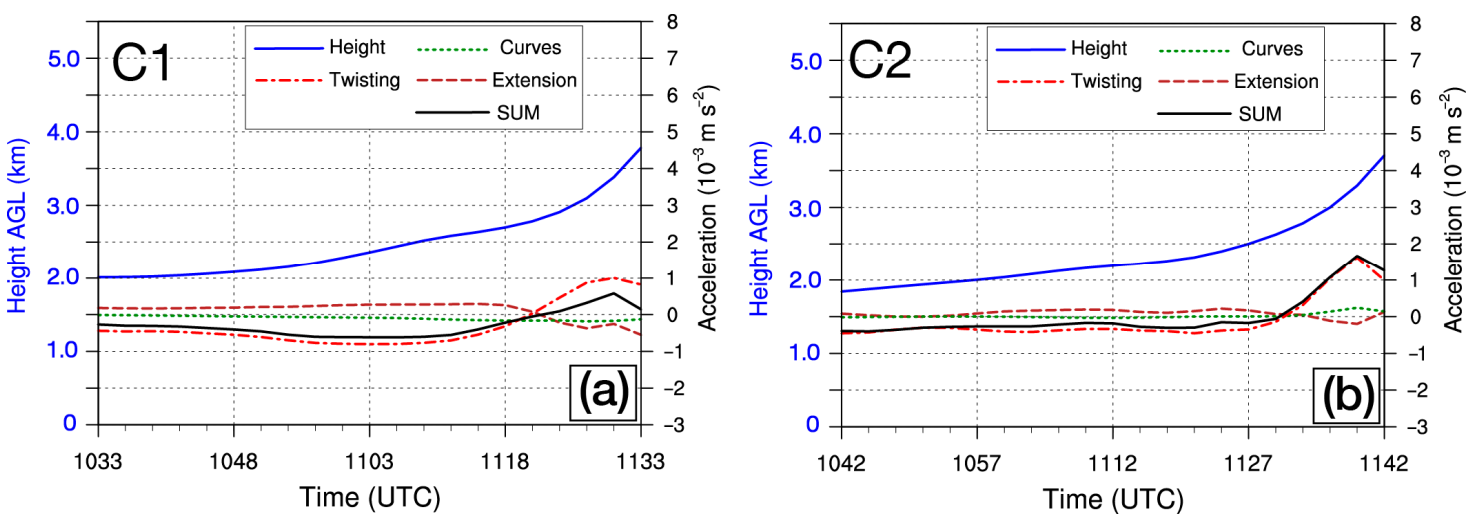

Figure 11. (a) Average height and three components (Curves, Twisting and Extension) of the dynamic acceleration $\left(a_{d}\right)$ and sum of them (SUM) along all air parcels selected within the C1. (b) is the same as (a) but for the $\mathrm{C} 2$. 
In order to obtain an intuitional understanding of the vertical twisting, the vertical cross section of the vertical shear of the horizontal wind along a line segment which almost runs parallel through the central region of the ground-relative backward trajectories of air parcels are analyzed (Figure 12). The vertical cross sections of vertical shear of the horizontal wind and averaged height of the backward trajectories and parcels at 6 min prior to the $C I$ along the three line segment (i.e., $A B, C D$ and $C^{\prime} D^{\prime}$ ) showed that (Figure $12 \mathrm{~d}-\mathrm{f}$ ), as the air parcels lifted significantly between $\sim 2.5-4 \mathrm{~km} \mathrm{AGL}$, they entered an area with high vertical shear of the horizontal wind. Consequently, it indicates that the air parcels encountered an environment with high vertical shear of the horizontal wind where the air parcels exhibited relatively large vertical twisting (analyzed above) due to the vertical wind shear prior to the CI. (The vertical shear of the horizontal wind was strengthened in a period about $1.5 \mathrm{~h}$ before the CI (figure not shown).)

The vertical momentum components (i.e., $a_{b}$ and $a_{d}$ ) along the two portions of air parcels from different directions within the $\mathrm{C} 2$ will be analyzed to verify the robustness of the conclusions (about the source of CI) drawn above. For the air parcels from southwest within the C2 (Figure 13a), the averaged $a_{b}$ along the air parcels was slightly greater than $a_{d}$ most of the time during the early $\sim 45 \mathrm{~min}$, and increased significantly during the last $\sim 15 \mathrm{~min}$. The $a_{d}$ also increased significantly and become slightly greater than $a_{b}$ during the last $\sim 15 \mathrm{~min}$. For the air parcels from south (Figure 13b), the averaged $a_{b}$ was greater than $a_{d}$ almost during the whole 1-h period, and showed a significant increasing trend in the last $\sim 15 \mathrm{~min}$. The $a_{d}$ also clearly increased during the last $\sim 15 \mathrm{~min}$, and showed almost the same value with $a_{b}$ at $\sim 3$ min prior to CI. The intensity of $a_{d}$ during the rapid lifting period (last $\sim 12 \mathrm{~min}$ ) for the air parcels from the southwest was greater than that of the air parcels from the south. This is probably due to that the height of the parcels from southwest was higher than that of the parcels from south, and was affected by higher vertical shear of horizontal wind, because the vertical shear of horizontal wind between 2.5-3.5 km was increased with height (see Figure 12e,f). Figure 13c,d show the evaluation of the averaged three components of $a_{d}$ along the air parcels from the southwest and south, respectively. It can be found that their overall features are almost the same, as shown in Figure $11 \mathrm{a}, \mathrm{b}-$-i.e., $a_{d}$ was dominated by the vertical twisting term in the rapid lifting period.

An important issue related to the mechanisms of CIs in this case that remains unclear is the reason for $a_{b}$. In order to investigate the possible source of $a_{b}$, the vertical cross section of potential temperature anomaly along the three line segments (i.e., $\mathrm{AB}, \mathrm{CD}$ and $\mathrm{C}^{\prime} \mathrm{D}^{\prime}$ ) are analyzed in the following section (Figure 14). For C1, there was a positive potential temperature anomaly in the surrounding environment of the averaged height of the air parcels during the early slow lifting period (Figure 14a). Similarly, the environment near the average height of the air parcels exhibited a positive potential temperature anomaly for the air parcels from the south within C2 during the early slow lifting period (Figure 14g). Therefore, this implies that the warming in the level below $\sim 2.5 \mathrm{~km}$ AGL was the reason of the $a_{b}$ which caused the slow lifting of the air parcels elevated from lower altitude for both $\mathrm{C} 1$ and C2 during the early $\sim 45 \mathrm{~min}$. During the last $\sim 15 \mathrm{~min}$ for $\mathrm{C} 1$ (Figure $14 \mathrm{~b}, \mathrm{c}$ ), the average height of the air parcels reached a level above $\sim 2.7 \mathrm{~km}$ AGL, and its upper environment obviously warmed with time, showing a significant warm core several minutes prior to CI. A similar phenomenon can roughly be found near the average height of the air parcels within C2 (Figure 14f,i). Consequently, this implies that this kind of warming during the last $\sim 15 \mathrm{~min}$ is the contributor to the $a_{b}$ for both convective cells.

The vertical cross sections of total hydrometeors (including cloud, graupel, rain, ice and snow) along the three line segments can explain the reason for warming during the last 15 min prior to CI. It is clearly shown in Figure 15 that there were a considerable number of hydrometeors that began to occur due to the condensation of water vapor when air parcels reached the level of condensation level (LCL) (i.e., $\sim 2.7 \mathrm{~km} \mathrm{AGL),} \mathrm{along} \mathrm{with} \mathrm{release} \mathrm{of} \mathrm{latent} \mathrm{heat.} \mathrm{(Among} \mathrm{the} \mathrm{five} \mathrm{hydrometeors} \mathrm{(i.e.,} \mathrm{cloud,}$ graupel, rain, ice and snow), the cloud water mixing ratio is the largest contributor, the graupel and snow mixing ratio show relatively weak intensity, and considered as the second and third contributor, respectively. However, the ice and rainwater mixing ratio are too small and are almost negligible 
(figure not shown).) Therefore, it can be concluded that the release of the latent heat is the reason for the rapid increase in the $a_{b}$ during the last $\sim 15 \mathrm{~min}$ prior to the CI for both convective cells.
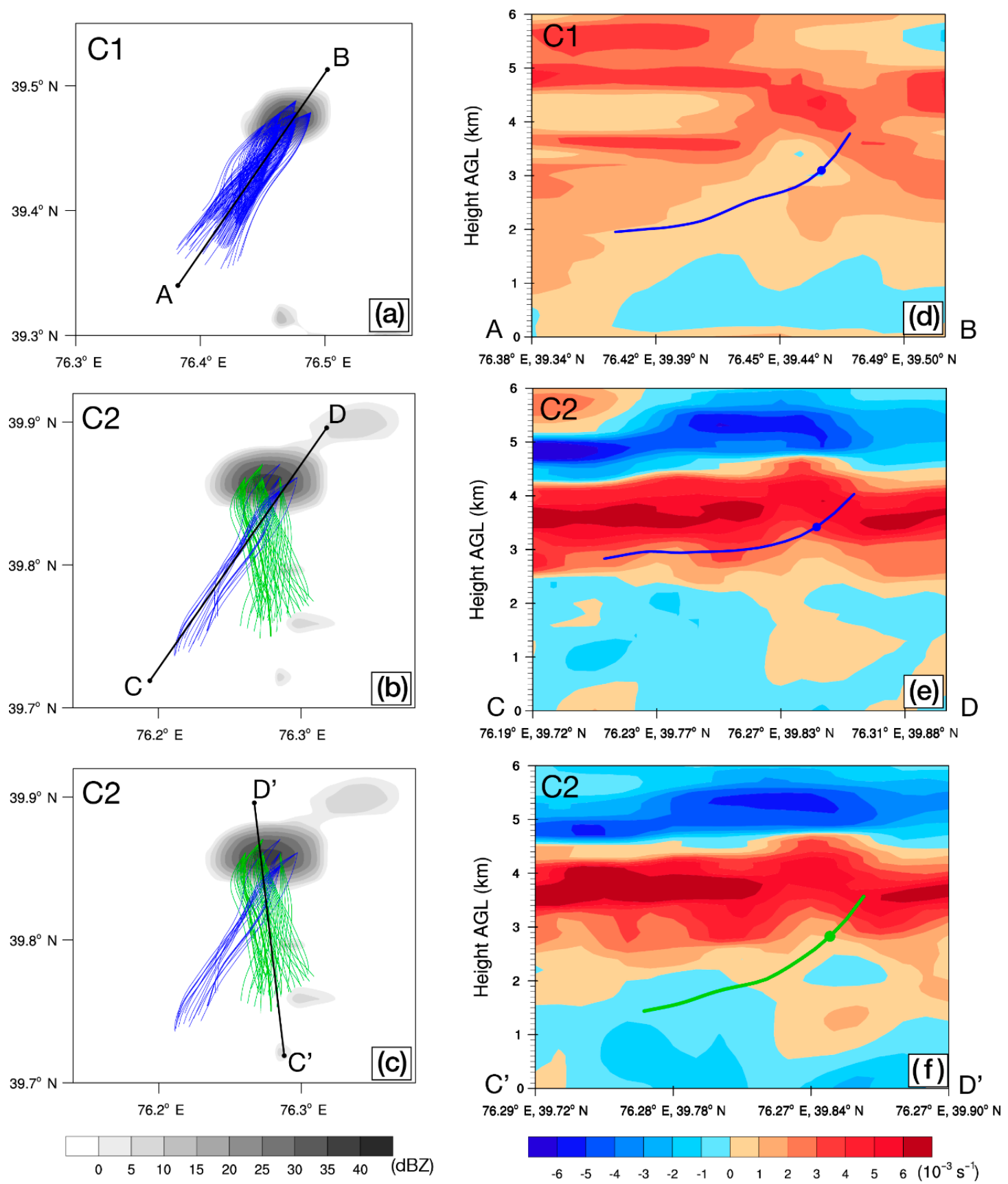

Figure 12. (a) Simulated composite reflectivity (shading; unit: dBZ) and ground-relative backward trajectories (blue lines, projected to the ground) of air parcels for $1 \mathrm{~h}$ within the C1 released at 1133 UTC. $(\mathbf{b}, \mathbf{c})$ are the same as (a) but for the ground-relative backward trajectories from southwest (south) are colored in blue (green) within the C2 released at 1142 UTC. (d) Vertical cross sections of vertical shear of the horizontal wind (shading, unit: $10^{-3} \cdot \mathrm{s}^{-1}$ ) and averaged height of the backward trajectories (bold blue line) and air parcels at 1127 UTC (bold blue dot) (projected to the vertical cross section) along the line segment AB. $(\mathbf{e}, \mathbf{f})$ are the same as $(\mathbf{d})$ but for the average height of the backward trajectories and air parcels at 1136 UTC that came from the southwest (south) are colored in blue (green) along the line segments $C D$ and $C^{\prime} D^{\prime}$, respectively. 

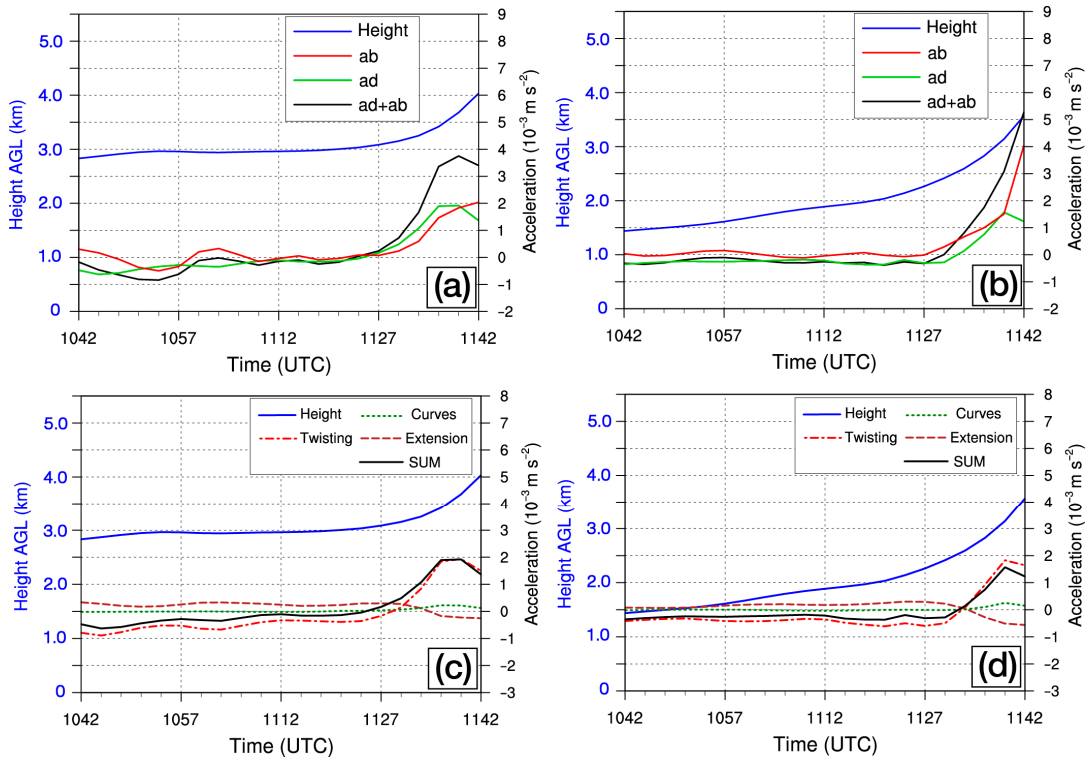

Figure 13. (a) Averaged height and vertical momentum components induced by buoyancy $\left(a_{d}\right)$, dynamical force $\left(a_{d}\right)$ and sum of them $\left(a_{b}+a_{d}\right)$ along the air parcels from southwest within the C2. (b) is the same as (a) but for the air parcels from south within the C2. (c) Averaged height and three components (curves, twisting and extension) of the dynamic acceleration $\left(a_{d}\right)$ and sum of them (SUM) along the air parcels from southwest within the C2. (d) is the same as (c) but for the air parcels from south within the $\mathrm{C} 2$.
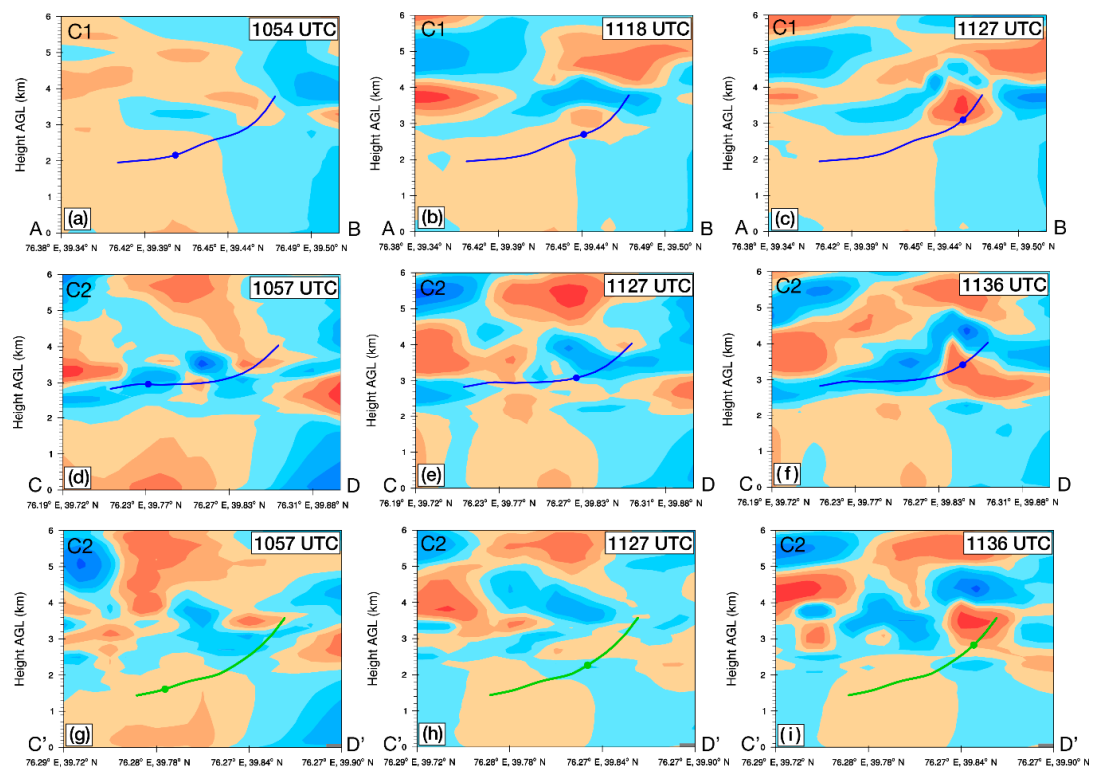

$-1-08-06-04-02-01000102040608-1(K)$

Figure 14. (a-c) Vertical cross sections of potential temperature anomaly (shading, unit: K) and averaged height of the backward trajectories (bold blue line) and air parcels (bold blue dot) (projected to the vertical cross section) selected within the $C 1$ along the line segment $A B$ in Figure 12a on 23 June 2015. (d-f) are the same as $(\mathbf{a}-\mathbf{c})$ but for the average height of the backward trajectories from southwest (blue lines in Figure 12b,c) along the line segment CD in Figure 12b. (g-i) are the same as (d-f) but for the average height of the backward trajectories from the south (green lines in Figure 12b,c) along the line segment $C^{\prime} \mathrm{D}^{\prime}$ in Figure 12c. The specific time is shown in the upper right corner of each panel. 

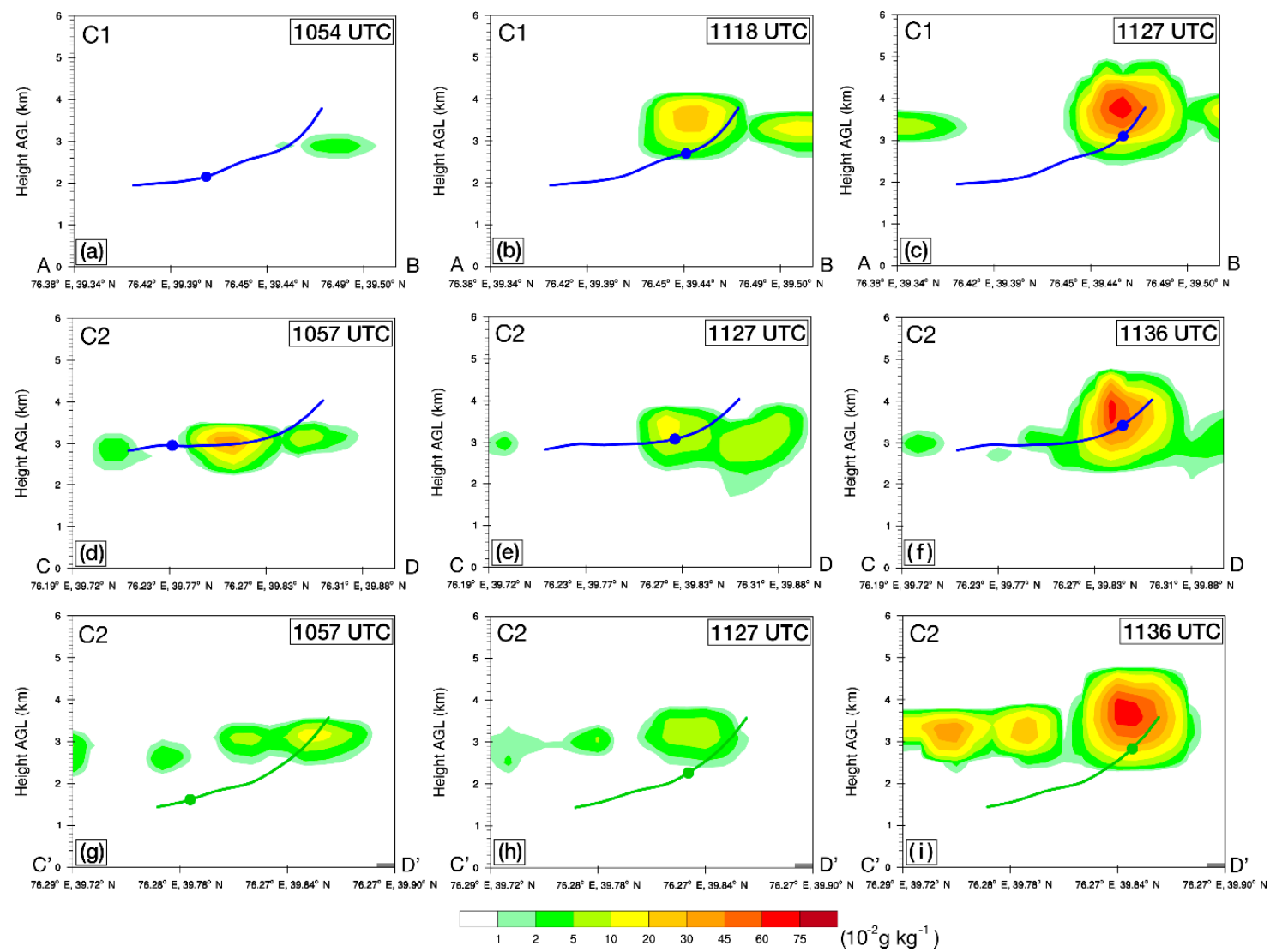

Figure 15. (a-i) The same as Figure 14a-i but for the vertical cross sections of hydrometeors (including cloud, graupel, rain, ice and snow) (shading, unit: $10^{-2} \mathrm{~g} \cdot \mathrm{kg}^{-1}$ ) on 23 June 2015. The specific time is shown in the upper right corner of each panel.

The reason for warming during the rapid lifting period during the last $\sim 15 \mathrm{~min}$ prior to the $\mathrm{CI}$ was analyzed above. However, one more issue about the reason for warming in the low level (below $2.5 \mathrm{~km}$ AGL) is still unclear. In order to figure out the reason, the plane figures of potential temperature and wind field were analyzed. It was found that there was a significant warm advection from the southeast at $3000 \mathrm{~m}$ above sea level (ASL) during the time 1 2 $\mathrm{h}$ prior to the CI (Figure 16a,b) (The altitude of the area where the two convective cell occurred is $\sim 1400 \mathrm{~m}$ ASL.) It can be seen from the bigger scope of the area that (Figure 16c,d), there was significant radiative heating from 0800 UTC (i.e., 1400 local time) to 1100 UTC (i.e., 1700 local time) near the mountainous area on the south side of the Tarim Basin. Besides, the southeasterlies strengthened with time and generated a significant warm advection from the southeast to the study area, thus causing warming in the low-level $1 \sim 2 \mathrm{~h}$ prior to the CI. (The potential temperature and wind field at $3500 \mathrm{~m}$ ASL showed almost the same feature (figure not shown)). 

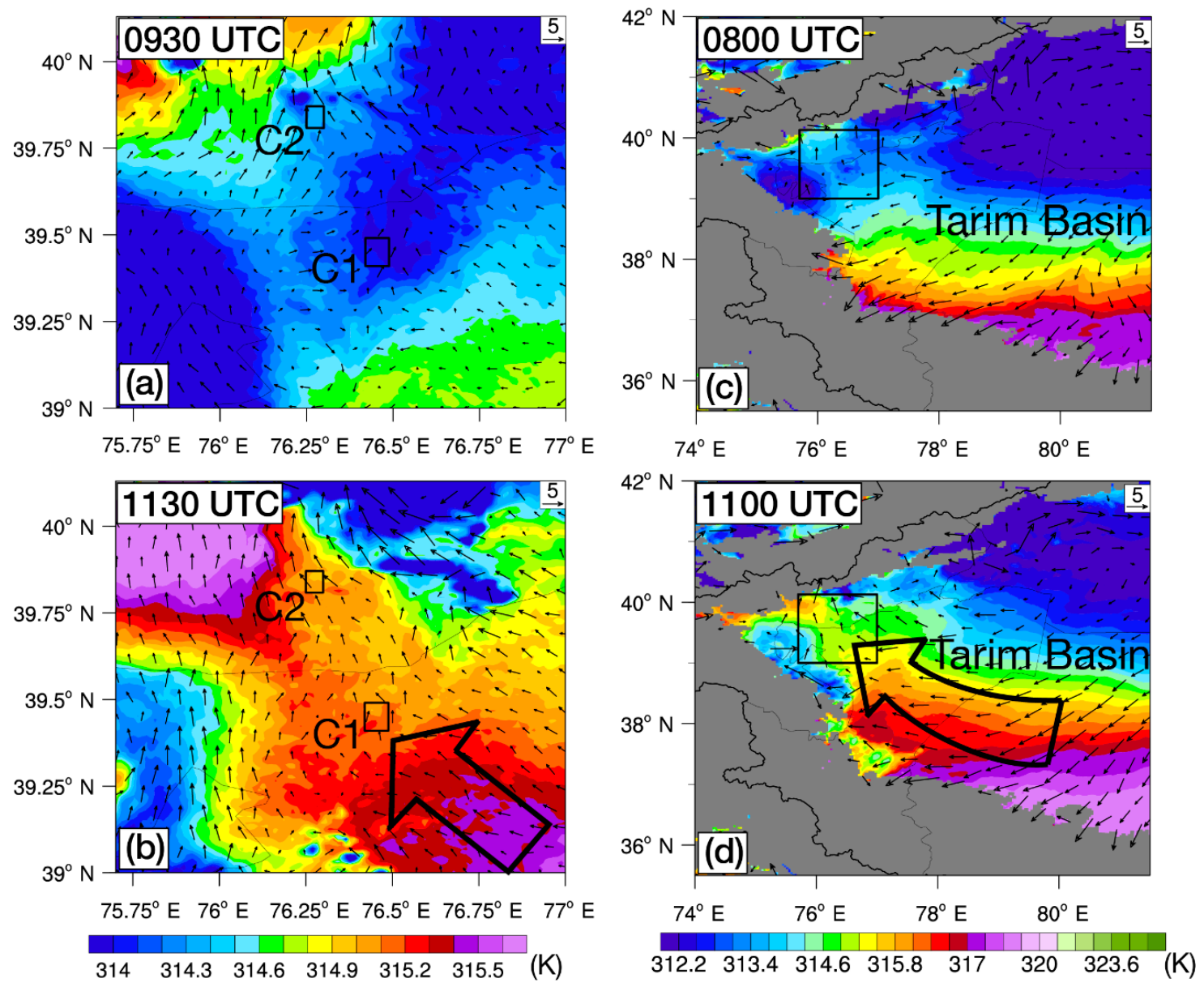

Figure 16. (a,b) Potential temperature (shading, unit: K) and wind field (arrows, unit: $\mathrm{m} \cdot \mathrm{s}^{-1}$ ) at $3000 \mathrm{~m}$ ASL on 23 June 2015. The small boxes denote the area where the $C 1$ and $C 2$ occurred, the black hollow arrow indicates the warm advection from the southeast. $(\mathbf{c}, \mathbf{d})$ are the same as $(\mathbf{a}, \mathbf{b})$ but for a bigger scope at different times, the box shows the area shown in the left panels. The gray areas indicate the topography. The specific time is shown in the upper left corner of each panel.

\section{Summary and Discussion}

This work investigated the mechanisms of convection initiation (CI) occurring in the southwestern Xinjiang province in Northwest China, on 23 June 2015, as the first in-depth study into CI in this region. Doppler weather radar observations showed that many CIs took place repeatedly, and more than half of them underwent rapid development in both size and intensity, and eventually formed an intense mesoscale convective system (MCS), producing severe convective weather, such as short-term high winds, heavy rainfall and hail. This case was numerically simulated via the Weather Research and Forecasting (WRF) model (V3.7) with a horizontal resolution of $1 \mathrm{~km}$. The WRF simulation accurately reproduced the overall pattern and features of the CIs and the associated MCS despite some biases in location, time and intensity.

In order to understand the mechanisms of $\mathrm{CI}$ in this case, fine-scale quantitative Lagrangian vertical momentum budget analysis was conducted along the backward trajectories of air parcels within two typical convective cells ( $\mathrm{C} 1$ and $\mathrm{C} 2$ ). The vertical acceleration was decomposed into contributions from buoyant acceleration $\left(a_{b}\right)$ and dynamic acceleration $\left(a_{d}\right)$, respectively. It was found that, from the perspective of averaged trajectory of air parcels, the slow lifting in the early $\sim 45 \mathrm{~min}$ was contributed to by $a_{b}$ for both convective cells. The rapid lifting of the air parcels within the $\mathrm{C} 1$ was mainly induced by $a_{b}$, while $a_{d}$ also showed a relatively weak positive contribution. For $\mathrm{C} 2, a_{b}$ also made a significant 
contribution to the rapid lifting of air parcels, while $a_{d}$ also exhibited a remarkable positive effect on the CI.

Furthermore, $a_{d}$ was decomposed into three terms-i.e., extension, horizontal curvature and vertical twisting. During the rapid lifting period of $\mathrm{CI}$ in both $\mathrm{C} 1$ and $\mathrm{C} 2$, the vertical twisting term was remarkably greater than the other two terms and thus dominated the $a_{d}$. However, the extension and horizontal curvature term showed very weak value. Therefore, it can be concluded that $a_{d}$ was mainly caused by the vertical twisting.

The vertical cross section of vertical shear of horizontal wind revealed that the air parcels encountered an environment with high vertical shear of horizontal wind in lower-to-middle level ( 2.5-4 km AGL) where the air parcels exhibited relatively large vertical twisting due to the vertical shear. Our previous study focusing on the CI mechanisms in the Bohai Bay region, North China [31] also found that the vertical twisting related to the horizontal vorticity caused by the vertical shear has the greatest contribution to the $\mathrm{CI}$, which is consistent with the result related to the cause of the $a_{d}$ in our present study. This differs from the RKW theory [54] which focused on the low-level vertical shear and the cold-pool depth.

Further analysis of potential temperature anomaly and hydrometeors showed that the warming in the level below $\sim 2.5 \mathrm{~km}$ AGL was the reason of the slow lifting of the air parcels elevated from lower altitude for both $\mathrm{C} 1$ and $\mathrm{C} 2$ during the early $\sim 45 \mathrm{~min}$. Besides, the release of latent heat when the air parcels reached the level of condensation level (LCL) (i.e., $\sim 2.7 \mathrm{~km} \mathrm{AGL)} \mathrm{is} \mathrm{the} \mathrm{reason} \mathrm{for} \mathrm{the}$ rapid increase in $a_{b}$ during the last $\sim 15$ min prior to the CI for both convective cells. In addition, it was found that there was a significant radiative heating near the mountainous area on the south side of the Tarim Basin in the afternoon. The southeasterlies generated a significant warm advection from the southeast to the study area, which caused warming in the low-level $1 \sim 2 \mathrm{~h}$ prior to the CI. The special arid and semiarid geographical features of the south Xinjiang played an important role for the warming during the slow lifting period of air parcels in the CI mechanism in this study. The Tarim Basin is mainly covered by Taklimakan desert and is surrounded by mountains. The land surface mainly covered by desert, and gobi in this area can provide quite strong long wave radiation and thus significantly heat the planetary boundary layer, and further contribute to the buoyant acceleration of the CI during the afternoon. To our knowledge, detailed quantitative diagnostic study on the $\mathrm{CI}$ in southwestern Xinjiang, Northwest China, has not been previously addressed in the literature, although numerous CI mechanisms around the world have been proposed through considering a great variety of weather systems. However, most of them are associated with dynamic lifting. However, the CI mechanism in the present study, in which the buoyant forcing played a major role, is significantly different from the mechanisms in many studies conducted in other places. For instance, Wilson and Roberts [4] summarized the CI related processes during the International $\mathrm{H}_{2} \mathrm{O}$ Project (IHOP_2002) experiment in the southern Great Plains in the Unites States. They pointed out that numerous boundary types, including drylines, cold pool outflow boundaries, cold fronts, horizontal convective rolls, topographically induced boundaries and bores, have played a crucial role in the CI. The present study provides some new insights into the roles of buoyant and dynamic forcings and hence helps improve the understanding of CI mechanisms. With a better understanding of the behavior of CI, these results can contribute to the improvement of quantitative precipitation forecasts, hazard prevention and reduction.

Author Contributions: Data curation: A.A.; Formal analysis: A.A., J.M.; Investigation: A.A., J.M.; Methodology: J.M., Y.W., X.X., X.Z.; Project administration: J.M.; Resources: M.A., B.Y., Y.Z.; Software: A.A., S.Z., X.Z.; Supervision: J.M.; Validation: A.A., J.M., X.X.; Writing—original draft: A.A., J.M., X.X.; Writing一review and editing: A.A., J.M., X.X. All authors have read and agreed to the published version of the manuscript.

Funding: This work was supported by the National Key R\&D Program of China (2018YFC1507103), National Natural Science Fund of China (41705032), Doctoral Research Startup Foundation of Xinjiang University (50500/62031224618), and 100 Young Doctors Introduction Program of Xinjiang (Tianchi Doctor Program) Foundation (50500/04231200737). 
Acknowledgments: We thank the High Performance Computing Center of Nanjing University for doing the numerical calculations in this paper on its IBM Blade cluster system.

Conflicts of Interest: The authors declare no conflict of interest.

\section{References}

1. Markowski, P. Convective storm initiation and organization. In Atmospheric Convection: Research and Operational Forecasting Aspects; Giaiotti, D.B., Steinacker, R., Stel, F., Eds.; Springer Wien: New York, NY, USA, 2007; pp. 23-28.

2. Weckwerth, T.M.; Parsons, D.B.; Koch, S.E.; Moore, J.A.; LeMone, M.A.; Demoz, B.B.; Flamant, C.; Geerts, B.; Wang, J.; Feltz, W.F. An overview of the International $\mathrm{H}_{2} \mathrm{O}$ Project (IHOP_2002) and some preliminary highlights. Bull. Am. Meteorol. Soc. 2004, 85, 253-277. [CrossRef]

3. Weckwerth, T.M.; Parsons, D.B. A review of convection initiation and motivation for IHOP_2002. Mon. Weather Rev. 2006, 134, 5-22. [CrossRef]

4. Wilson, J.W.; Roberts, R.D. Summary of convective storm initiation and evolution during IHOP: Observational and modeling perspective. Mon. Weather Rev. 2006, 134, 23-47. [CrossRef]

5. Lock, N.A.; Houston, A.L. Empirical examination of the factors regulating thunderstorm initiation. Mon. Weather Rev. 2014, 142, 240-258. [CrossRef]

6. Zhang, Y.; Zhang, F.; Stensrud, D.J.; Meng, Z. Practical predictability of the 20 May 2013 tornadic thunderstorm event in Oklahoma: Sensitivity to synoptic timing and topographical influence. Mon. Weather Rev. 2015, 143, 2973-2997. [CrossRef]

7. Zhang, Y.; Zhang, F.; Stensrud, D.J.; Meng, Z. Intrinsic predictability of the 20 May 2013 tornadic thunderstorm event in Oklahoma at storm scales. Mon. Weather Rev. 2016, 144, 1273-1298. [CrossRef]

8. Du, Y.; Chen, G. Heavy rainfall associated with double low-level jets over southern China. Part II: Convection initiation. Mon. Weather Rev. 2019, 147, 543-565. [CrossRef]

9. Bai, L.; Chen, G.; Huang, L. Image processing of radar mosaics for the climatology of convection initiation in south China. J. Appl. Meteorol. Climatol. 2020, 59, 65-81. [CrossRef]

10. Kain, J.S.; Coniglio, M.C.; Correia, J.; Clark, A.J.; Marsh, P.T.; Ziegler, C.L.; Lakshmanan, V.; Miller, S.D., Jr.; Dembek, S.R.; Weiss, S.J.; et al. A feasibility study for probabilistic convection initiation forecasts based on explicit numerical guidance. Bull. Am. Meteorol. Soc. 2013, 94, 1213-1225. [CrossRef]

11. Burghardt, B.; Evans, J.C.; Roebber, P.J. Assessing the predictability of convection initiation in the Hugh Plains using an object-based approach. Weather Forecast. 2014, 29, 403-418. [CrossRef]

12. Clark, P.A.; Browning, K.A.; Morcrette, C.J.; Blyth, A.M.; Forbes, R.M.; Brooks, B.; Perry, F. The evolution of an MCS over southern England. Part 1: Observations. Quart. J. R. Meteorol. Soc. 2014, 140, 439-457. [CrossRef]

13. Weckwerth, T.M.; Hanesiak, J.M.; Wilson, J.W.; Trier, S.B.; Degelia, S.K.; Gallus, W.A., Jr.; Roberts, R.D.; Wang, X. Nocturnal convection initiation during PECAN 2015. Bull. Am. Meteorol. Soc. 2019, 100, 2223-2239. [CrossRef]

14. Trier, S.B.; Kehler, S.D.; Hanesiak, J. Observations and simulation of elevated nocturnal convection initiation on 24 June 2015 during PECAN. Mon. Weather Rev. 2020, 148, 613-635. [CrossRef]

15. Schaefer, J.T. Severe thunderstorm forecasting: A historical perspective. Weather Forecast. 1986, 1, $164-189$. [CrossRef]

16. Johns, R.H.; Doswell, C.A. Severe local storms forecasting. Weather Forecast. 1992, 7, 588-612. [CrossRef]

17. Bluestein, H.B.; Snyder, J.C. An observational study of the effects of dry air produced in dissipating convective storms on the predictability of severe weather. Weather Forecast. 2015, 30, 79-114. [CrossRef]

18. Banta, R.M.; Schaaf, C.B. Thunderstorm genesis zones in the Colorado Rocky Mountains as determined by traceback of geosynchronous satellite images. Mon. Weather Rev. 1987, 115, 463-476. [CrossRef]

19. Weckwerth, T.M.; Wilson, J.W.; Hagen, M.; Emerson, T.J.; Pinto, J.O.; Rife, D.L.; Grebe, L. Radar climatology of the COPS region. Quart. J. R. Meteorol. Soc. 2011, 137, 31-41. [CrossRef]

20. Jeong, J.-H.; Lee, D.-I.; Wang, C.-C. Impact of the cold pool on mesoscale convective system-produced extreme rainfall over southeastern south Korea: 7 July 2009. Mon. Weather Rev. 2016, 144, 3985-4006. [CrossRef] 
21. Wang, C.-C.; Kirshbaum, D.J.; Sills, D.M.L. Convection initiation aided by lake-breeze convergence over the Niagara Peninsula. Mon. Weather Rev. 2019, 147, 3955-3979. [CrossRef]

22. Klemp, J.B.; Rotunno, R. A Study of the Tornadic Region within a Supercell Thunderstorm. J. Atmos. Sci. 1983, 40, 359-377. [CrossRef]

23. Weisman, M.L.; Trapp, R.J. Low-level mesovortices within squall lines and bow echoes. Part I: Overview and dependence on environmental shear. Mon. Weather Rev. 2003, 131, 2779-2803. [CrossRef]

24. Xu, X.; Xue, M.; Wang, Y. Mesovortices within the 8 May 2009 bow echo over the central United States: Analyses of the characteristics and evolution based on doppler radar observations and a high-resolution model simulation. Mon. Weather Rev. 2015, 143, 2266-2290. [CrossRef]

25. Schenkman, A.D.; Xue, M.; Dawson, D.T., II. The cause of internal outflow surges in a high-resolution simulation of the 8 May 2003 Oklahoma City tornadic supercell. J. Atmos. Sci. 2016, 73, 353-370. [CrossRef]

26. Wang, C.-C.; Chen, G.T.-J.; Huang, S.-Y. Remote trigger of deep convection by cold outflow over the Taiwan strait in the Mei-Yu season: A modeling study of the 8 June 2007 case. Mon. Weather Rev. 2011, 139, 2854-2875. [CrossRef]

27. Xu, W.; Zipser, E.J.; Chen, Y.-L.; Liu, C.; Liou, Y.-C.; Lee, W.-C.; Jou, B.J.-D. An orography-associated extreme rainfall event during TiMREX: Initiation, storm evolution, and maintenance. Mon. Weather Rev. 2012, 140, 2555-2574. [CrossRef]

28. Wang, H.; Luo, Y.L.; Jou, B.J.D. Initiation, maintenance, and properties of convection in an extreme rainfall event during SCMREX: Observational analysis. J. Geophys. Res. Atmos. 2014, 119, 13206-13232. [CrossRef]

29. Abulikemu, A.; Xu, X.; Wang, Y.; Ding, J.F.; Wang, Y. Atypical occlusion process caused by the merger of a sea-breeze front and gust front. Adv. Atmos. Sci. 2015, 32, 1431-1443. [CrossRef]

30. Abulikemu, A.; Xu, X.; Wang, Y.; Ding, J.; Zhang, S.; Shen, W. A modeling study of convection initiation prior to the merger of a sea-breeze front and a gust front. Atmos. Res. 2016, 182, 10-19. [CrossRef]

31. Abulikemu, A.; Wang, Y.; Gao, R.; Wang, Y.; Xu, X. A numerical study of convection initiation associated with a gust front in Bohai Bay region, North China. J. Geophys. Res. Atmos. 2019, 124, 13843-13860. [CrossRef]

32. Xu, X.; Xue, M.; Wang, Y.; Huang, H. Mechanisms of secondary convection within a Mei-Yu frontal mesoscale convective system in eastern China. J. Geophys. Res. Atmos. 2017, 122, 47-64. [CrossRef]

33. Liang, Z.; Wang, D.; Liu, Y.; Cai, Q. A numerical study of the convection triggering and propagation associated with sea-breeze circulation over Hainan Island. J. Geophys. Res. Atmos. 2017, 122, 8567-8592. [CrossRef]

34. Zhang, M.; Meng, Z.; Huang, Y.; Wang, D. The mechanism and predictability of an elevated convection initiation event in a weak-lifting environment in central-eastern China. Mon. Weather Rev. 2019, 147, 1823-1841. [CrossRef]

35. Bai, L.; Meng, Z.; Huang, Y.; Zhang, Y.; Niu, S.; Su, T. Convection initiation resulting from the interaction between a quasi-stationary dryline and intersecting gust fronts: A case study. J. Geophys. Res. Atmos. 2019, 124, 2379-2396. [CrossRef]

36. Luo, Y.; Gong, Y.; Zhang, D.-L. Initiation and organizational modes of an extreme-rain-producing mesoscale convective system along a Mei-Yu front in east China. Mon. Weather Rev. 2014, 142, 203-221. [CrossRef]

37. Chen, X.; Zhang, F.; Zhao, K. Diurnal variations of the land-sea breeze and its related precipitation over south China. J. Atmos. Sci. 2016, 73, 4793-4815. [CrossRef]

38. Mahoney, W.P. Gust front characteristics and the kinematics associated with interacting thunderstorm outflows. Mon. Weather Rev. 1988, 116, 1474-1491. [CrossRef]

39. Harrison, S.J.; Mecikalski, J.R.; Knupp, K.R. Analysis of outflow boundary collisions in north-central Alabama. Weather Forecast. 2009, 24, 1680-1690. [CrossRef]

40. Skamarock, W.C.; Klemp, J.B.; Dudhia, J.; Gill, D.O.; Barker, D.M.; Duda, M.G.; Huang, X.Y.; Wang, W.; Powers, J.G. A Description of the Advanced Research WRF Version 3; University Corporation for Atmospheric Research: Boulder, CO, USA, 2008. [CrossRef]

41. Xu, X.; Xue, M.; Wang, Y. The genesis of mesovortices within a real-data simulation of a bow echo system. J. Atmos. Sci. 2015, 72, 1963-1986. [CrossRef]

42. Hong, S.-Y.; Lim, J.O.J. The WRF single-moment 6-class microphysics scheme (WSM6). J. Korean Meteorol. Soc. 2006, 42, 129-151.

43. Pleim, J.E. A combined local and nonlocal closure model for the atmospheric boundary layer. Part I: Model description and testing. J. Appl. Meteorol. Climatol. 2007, 46, 1383-1395. [CrossRef] 
44. Mlawer, E.J.; Taubman, S.J.; Brown, P.D.; Iacono, M.J.; Clough, S.A. Radiative transfer for inhomogeneous atmospheres: RRTM, a validated correlated-k model for the longwave. J. Geophys. Res. Atmos. 1997, 102, 16663-16682. [CrossRef]

45. Tewari, M.; Chen, F.; Wang, W.; Dudhia, J.; LeMone, M.A.; Mitchell, K.; Ek, M.; Gayno, G.; Wegiel, J.; Cuenca, R.H. Implementation and verification of the unified NOAH land surface model in the WRF model. In Proceedings of the 20th Conference on Weather Analysis and Forecasting/16th Conference on Numerical Weather Prediction, Seattle, WA, USA, 14 January 2004. Available online: https://ams.confex.com/ams/ 84Annual/techprogram/paper_69061.htm (accessed on 4 November 2020).

46. Jimenez, P.A.; Dudhia, J.; Gonzalez-Rouco, J.F.; Navarro, J.; Montávez, J.P.; Garcia-Bustamante, E. A revised scheme for the WRF surface layer formulation. Mon. Weather Rev. 2012, 140, 898-918. [CrossRef]

47. Kain, J.S. The Kain-Fritsch convective parameterization: An update. J. Appl. Meteorol. 2004, 43, $170-181$. [CrossRef]

48. Jeevanjee, N.; Romps, D.M. Effective buoyancy, inertial pressure, and the mechanical generation of boundary layer mass flux by cold pools. J. Atmos. Sci. 2015, 72, 3199-3213. [CrossRef]

49. Xu, K.M.; Randall, D.A. Updraft and downdraft statistics of simulated tropical and midlatitude cumulus convection. J. Atmos. Sci. 2001, 58, 1630-1649. [CrossRef]

50. Davies-Jones, R. An expression for effective buoyancy in surroundings with horizontal density gradients. J. Atmos. Sci. 2003, 60, 2922-2925. [CrossRef]

51. Torri, G.; Kuang, Z.M.; Tian, Y. Mechanisms for convection triggering by cold pools. Geophys. Res. Lett. 2015, 42, 1943-1950. [CrossRef]

52. Adams, J.C. MUDPACK: Multigrid portable fortran software for the efficient solution of linear elliptic partial differential equations. Appl. Math. Comput. 1989, 34, 113-146. [CrossRef]

53. Dawson, D.T.; Xue, M.; Shapiro, A.; Milbrandt, J.A.; Schenkman, A.D. Sensitivity of real-data simulations of the 3 May 1999 Oklahoma City tornadic supercell and associated tornadoes to multimoment microphysics. Part II: Analysis of buoyancy and dynamic pressure forces in simulated tornado-like vortices. J. Atmos. Sci. 2016, 73, 1039-1061. [CrossRef]

54. Rotunno, R.; Klemp, J.B.; Weisman, M.L. A theory for strong, long-lived squall lines. J. Atmos. Sci. 1988, 45, 463-485. [CrossRef]

Publisher's Note: MDPI stays neutral with regard to jurisdictional claims in published maps and institutional affiliations.

(C) 2020 by the authors. Licensee MDPI, Basel, Switzerland. This article is an open access article distributed under the terms and conditions of the Creative Commons Attribution (CC BY) license (http://creativecommons.org/licenses/by/4.0/). 